\title{
Green Synthesis, Characterization and Application of Natural Product Coated Magnetite Nanoparticles for Wastewater Treatment
}

\author{
Chanchal Das ${ }^{1}{ }^{(\mathbb{D}}$, Subhadeep Sen ${ }^{1}{ }^{(\mathbb{D}}$, Tejinder Singh $^{2}$, Tanmoy Ghosh ${ }^{3}$, Subha Sankar Paul ${ }^{4} \mathbb{D}^{\mathbb{B}}$, \\ Tae Wan Kim ${ }^{5}$, Seob Jeon ${ }^{6}\left(\mathbb{D}\right.$, Dilip K. Maiti ${ }^{3, *} \mathbb{0}$, Jungkyun $\operatorname{Im}^{2,7, *(\mathbb{D}}$ and Goutam Biswas ${ }^{1, *(\mathbb{C})}$ \\ 1 Department of Chemistry, Cooch Behar Panchanan Barma University, Vivekananda Street, \\ Cooch Behar 736101, West Bengal, India; chanchaldas453@gmail.com (C.D.); \\ sensubhadeep07@gmail.com (S.S.) \\ 2 Department of Electronic Materials and Devices Engineering, Soonchunhyang University, \\ Asan 31538, Korea; tejinder@sch.ac.kr \\ 3 Department of Chemistry, University of Calcutta, 92 A. P. C. Road, Kolkata 700009, India; \\ tanmoyghoshchem@gmail.com \\ 4 Singapore Center for Environmental Life Sciences Engineering, Nanyang Technological University, \\ Singapore 637551, Singapore; sankarsuvo@gmail.com \\ 5 Department of Medical Life Science, Soonchunhyang University, Asan 31538, Korea; ktwdreem@naver.com \\ 6 Department of Obstetrics and Gynecology, College of Medicine, Soonchunhyang University, \\ Cheonan Hospital, Cheonan 31151, Korea; sjeon4595@gmail.com \\ 7 Department of Chemical Engineering, Soonchunhyang University, Asan 31538, Korea \\ * Correspondence: dkmchem@caluniv.ac.in (D.K.M.); jkim5279@sch.ac.kr (J.I.); goutam@cbpbu.ac.in (G.B.); \\ Tel.: +82-41-530-1360 (J.I.)
}

Received: 13 July 2020; Accepted: 13 August 2020; Published: 18 August 2020

\begin{abstract}
Adsorption of organic pollutants, toxic metal ions, and removal of harmful bacteria can give us clean and pure drinkable water from wastewater resources. Respective magnetite nanoparticles (MNPs) were synthesized using a cheaper and greener way in an open-air environment with the use of crude latex of Jatropha curcas (JC) and leaf extract of Cinnamomum tamala (CT). Characterization of MNPs had been performed by dynamic light scattering (DLS), Ultraviolet-visible (UV-vis) spectroscopy, Fourier-transform infrared (FTIR) spectroscopy, powdered X-ray diffraction (XRD), and field emission scanning electron microscope (FE-SEM). The size ranges of the synthesized MNPs were observed in between $20-42 \mathrm{~nm}$ for JC- $\mathrm{Fe}_{3} \mathrm{O}_{4}$ and within $26-35 \mathrm{~nm}$ for CT-Fe $\mathrm{O}_{4}$ by FE-SEM images. The effect of synthesized magnetic nanoparticles in wastewater treatment (bacterial portion), dye adsorption, toxic metal removal as well as antibacterial, antioxidant, and cytotoxic activities were studied. This purification will lead to an increase in the resources of pure drinking water in the future.
\end{abstract}

Keywords: magnetite nanoparticles; wastewater treatment; antibacterial; toxic metal removal; dye adsorption

\section{Introduction}

The freshwater scarcity and water pollution problems have been increasingly growing worldwide in the last several years [1]. At present, around 3.1\% of deaths happening every year, which is over 1.7 million all over the world, are caused just because of unsafe and lack of reliable sources of drinkable water [2]. It is estimated that more than $57 \%$ of the world's population will have difficulties in accessing water throughout the year by 2050 [1]. Water pollution is the principal cause for the lack of suitable drinking water resources. In every growing nation, importance on industry and agricultural evolution leads to contamination of water with harmful organic pollutants and metals like cobalt (Co), copper (Cu), 
nickel $(\mathrm{Ni})$, lead $(\mathrm{Pb})$, zinc $(\mathrm{Zn})$, arsenic $(\mathrm{As})$, cadmium $(\mathrm{Cd})$, chromium $(\mathrm{Cr})$, and mercury $(\mathrm{Hg})[3,4]$. Another important problem is waterborne harmful bacteria viz. Salmonella typhosa (typhoid), Vibrio cholerae (cholera), Escherichia coli (diarrhea), etc. This necessitates the urgency to remove toxins and impurities from aquatic environments rapidly and efficiently, by means of technological advancement. There are many physical, chemical, and biological purification methods available to remove organic pollutants, heavy metals, and harmful bacteria from wastewater. The adsorption technique is the most widely used physical technique, efficient to remove inorganic and organic pollutants from wastewater. Many natural and synthetic adsorbents have already been developed [5-7]. Among them, activated carbon, rice husk, carbon nanotubes, mesoporous silica, curcubiturils etc. are well-established materials [8-10].

In the last few decades, nanoparticles have emerged as one of the versatile tools for catalysis [11], biosensors [12], cell labelling [13], medicines [14], solar cells [15], fuel cells [16], photonic band gap materials [17], and in many more applications.

Nanoparticles (NPs) have very large surface area. Hence, they are more efficient to bind with various molecules [18]. The advantage of magnetite nanoparticles (MNPs) lies in its super paramagnetic behavior. Hence, MNPs have the added control of changing the concentration of nanoparticles by the simple use of the magnet. MNPs have been recently reported to be developed for the purification of wastewater [19-21]. The use of the magnetic field after purification to remove the nanoparticles makes the purification process simpler, cost-efficient, and safe to handle. MNPs are synthesized easily by different methods, among which the most popular and common is by the co-precipitation method [22,23]. The main drawback of MNPs is the aggregation, which is formed due to the lack of stabilizing agents. By suitable surface modifications, they can be produced in variable nanosize range and, therefore, can be useful in many applications like theranostic treatment and phototherapeutic treatment for heavy metal removal from groundwater [22,24]. Various surface modifier agents are used like polyethylene glycol (PEG) [25], $\mathrm{SiO}_{2}$ [26], ionic liquids [27], and extracts of different parts of plants to modify the size, stability from aggregation, and the biocompatibility of the MNPs [28,29]. MNPs can be conveniently prepared by the greener way and at low cost [30-32]. The multimodal properties of the MNPs have been utilized in many applications [33].

The Indian spice Cinnamomum tamala leaf is known for its antioxidant [34], as well as antibacterial properties [35], and similar properties are found in the case of Jatropha curcas latex as well [36,37]. Several MNPs have been synthesized with natural product extracts like neem [38], bhringraj [39], curcumin [40], etc. and are utilized as capping agents as well as stabilizing agents for nanoparticles. In all the cases, the antibacterial property, antioxidant property, and anti-cancer activity are some of the commonly explored properties.

Herein, we report the synthesis of two different nanoparticles CT- $\mathrm{Fe}_{3} \mathrm{O}_{4}$ and JC- $\mathrm{Fe}_{3} \mathrm{O}_{4}$ coated with Cinnamomum tamala (CT) leaves and Jatropha curcas (JC) latex extract respectively. To date, no literature has reported the green syntheses of above two natural products-based MNPs. The two nanoparticles $\mathrm{CT}-\mathrm{Fe}_{3} \mathrm{O}_{4}$ and JC- $\mathrm{Fe}_{3} \mathrm{O}_{4}$ are further characterized, and their applications in wastewater treatment as well as their antibacterial activity, antioxidant activity, and cytotoxicity have been explored.

\section{Chemicals and Experimental Methods}

\subsection{Materials Used}

Cinnamomum tamala leaves were procured commercially, whereas fresh Jatropha curcas latex was collected from Alipurduar district, West Bengal, India. Commercially available iron (II) chloride $\left(\mathrm{FeCl}_{2} \cdot \mathrm{H}_{2} \mathrm{O}\right)$, iron (III) chloride $\left(\mathrm{anh} . \mathrm{FeCl}_{3}\right)$ and the other reagents were of analytical grade and utilized without further purification. All the solutions were made by freshly prepared deionised water (DW). High glucose Dulbecco's modified Eagle's medium (DMEM), Roswell Park Memorial Institute (RPMI) 1640, Dulbecco's phosphate-buffered saline (DPBS, pH 7.4), fetal bovine serum (FBS), and trypsin/EDTA were procured from Gibco ${ }^{\mathrm{TM}}$, Thermo Fischer Scientific (Loughborough, 
UK). 3-(4,5-dimethylthiazol-2-yl)-2,5-diphenyl tetrazolium bromide (MTT) was purchased from Sigma Aldrich, Goyang, Korea. MilliQ purified water $(18.2 \mathrm{M} \Omega$ ) was used to prepare all biological solutions. Cancer cells, both SW480 and HeLa, were incubated at $37^{\circ} \mathrm{C}$ in a humidified $5 \% \mathrm{CO}_{2}$ environment in RPMI 1640 and 10\% (v/v) FBS with penicillin.

\subsection{Preparation of Aqueous Extract of CT Leaf and 3\% (v/v) JC Latex Extract}

Commercially available dried $20 \mathrm{~g}$ CT leaves were crushed into small pieces and washed with DW to remove any impurities. Then around $70 \mathrm{~mL}$ DW was added and boiled for $20 \mathrm{~min}$, filtered through Whatman-40 filter paper, and straw yellow leaf-extract was found to be around $30 \mathrm{~mL}$.

Freshly collected $3 \mathrm{~mL}$ of JC crude latex was mixed with $97 \mathrm{~mL}$ of DW to get $3 \%(v / v)$ solution of it. The optimum concentration of $3 \%$ latex solution was prepared because greater concentration makes it insoluble in water, and lower concentration was insufficient for nanoparticles synthesis [37].

\subsection{Preparation of $\mathrm{CT}-\mathrm{Fe}_{3} \mathrm{O}_{4} \mathrm{NPs}$}

$2.03 \mathrm{~g} \mathrm{FeCl}_{2} \cdot \mathrm{H}_{2} \mathrm{O}$ and $5.19 \mathrm{~g} \mathrm{FeCl}_{3}$ (anh.) were mixed, and $160 \mathrm{~mL}$ deionised water was added, stirred for $30 \mathrm{~min}$, followed by the addition of optimum $40 \mathrm{~mL} \mathrm{CT}$ aqueous leaf extract. Then $5.12 \mathrm{~g}$ $\mathrm{NaOH}$ in $80 \mathrm{~mL}$ DW was added to the mixture (to complete the precipitation) and the black solution was stirred further for about $60 \mathrm{~min}$ to complete the reaction and get the final black precipitate. Centrifugation was performed followed by washing with deionised water, repeatedly for 2-3 times to get the nanoparticles and was dried in vacuum desiccator for overnight to get the nanoparticles.

\subsection{Preparation of $\mathrm{JC}-\mathrm{Fe}_{3} \mathrm{O}_{4} \mathrm{NPs}$}

One-hundred milliters of DW was added to the mixture of $1.27 \mathrm{~g} \mathrm{FeCl}_{2} \cdot \mathrm{H}_{2} \mathrm{O}$ and $3.24 \mathrm{~g} \mathrm{FeCl}_{3}$ (anh.), stirred for $30 \mathrm{~min}$, followed by the addition of $125 \mathrm{~mL} \mathrm{3 \%} \mathrm{JC} \mathrm{latex;} 3.2 \mathrm{~g} \mathrm{NaOH}$ in $50 \mathrm{~mL} \mathrm{DW}$ was added to the mixture and stirred further for $50 \mathrm{~min}$ to complete the reaction. Centrifugate was washed with DW repeatedly two to three times, and then dried in a vacuum desiccator overnight to get the final nanopowder.

\subsection{Characterization of $\mathrm{CT}-\mathrm{Fe}_{3} \mathrm{O}_{4}$ and JC-Fe $\mathrm{O}_{3} \mathrm{O}_{4} \mathrm{NPS}$}

DLS (model ZETASIZER Nano Series Nano ZS, Malvern Panalytical, Malvern, UK) technique was used to get a rough idea about the average size and particle size distribution of respective nanoparticles (hydrated sphere). UV-Vis spectroscopy had been done by using Perkin Elmar instrument, Waltham, MA, USA). Clustered metallic oxides were investigated by powdered X-ray diffractometry using Rigaku Miniflex 600 (Japan) equipped with copper X-Ray tube (Cu-K $\alpha 1,2$ radiation) and NaI (Tl) scintillating detector. The surface morphology of the MNPs was studied using (FE-SEM, MIRA II LMH, Tescan, USA). Fourier-transform infrared spectroscopy (FTIR) was performed by using IR spectrometer (JASCO FT/IR-4600, Tokyo, Japan) with a resolution of $4 \mathrm{~cm}^{-1}$ and the scan range of $650-4000 \mathrm{~cm}^{-1}$. Magnetization measurements were performed on SQUID magnetometer (Quantum Design MPMS-7) from KBSI (Daejeon, South Korea).

\subsection{Dye Adsorption Experiment}

The dye adsorption study of the CT- $\mathrm{Fe}_{3} \mathrm{O}_{4}$ and JC- $\mathrm{Fe}_{3} \mathrm{O}_{4}$ NPs was performed by taking a known concentration of methylene blue (MB) $(200 \mathrm{mg} / \mathrm{L})$ solution and a definite quantity of MNPs $(50 \mathrm{mg})$ in a conical flask (at $\mathrm{pH} 7$ ), shaken thoroughly for $120 \mathrm{~min}$ at room temperature. At an interval of $20 \mathrm{~min}$, the optical density (OD) was checked for each solution at $660 \mathrm{~nm}$ for adsorption kinetic study. For another set of experiments, a series of different initial concentrations $(200 \mathrm{mg} / \mathrm{L}-500 \mathrm{mg} / \mathrm{L})$ of MB were shaken (at $\mathrm{pH} \sim 7$, room temperature) with MNPs $(50 \mathrm{mg}$ ) for $120 \mathrm{~min}$, and the optical density 
(OD) was checked for each solution for adsorption isotherm study. While collecting the samples, the nanoparticles were removed by application of an external magnetic field [41].

$$
\text { Removal of MB dye }(\%)=\left[\left(C_{o}-C_{e}\right) / C_{o}\right] \times 100
$$

$C_{o}=$ initial concentration of MB dye only, $C_{e}=$ concentration of MNPs solution (MB dye + MNPs) at equilibrium.

\subsection{Toxic Metal Adsorption Experiment (with Concentration)}

For metal adsorption study, we chose copper (II) acetate and cobalt (II) chloride as a source for copper $\left(\mathrm{Cu}^{2+}\right)$ and cobalt $\left(\mathrm{Co}^{2+}\right)$ ions, respectively. Five different concentrations $(400 \mathrm{mg} / \mathrm{L}, 600 \mathrm{mg} / \mathrm{L}$, $800 \mathrm{mg} / \mathrm{L}, 1200 \mathrm{mg} / \mathrm{L}$, and $1400 \mathrm{mg} / \mathrm{L}$ ) of both salt solutions were prepared ( $\mathrm{pH} \sim 7$, room temperature). Two milligrams of CT- $-\mathrm{Fe}_{3} \mathrm{O}_{4}$ NPs and $2.0 \mathrm{mg}$ of JC- $\mathrm{Fe}_{3} \mathrm{O}_{4}$ NPs were added separately to each test tube containing $5 \mathrm{~mL}$ of each salt solution and were ultrasonicated for $120 \mathrm{~min}$. Next the optical density (at $650 \mathrm{~nm}$ and $510 \mathrm{~nm}$ for $\mathrm{Cu}^{2+}$ and $\mathrm{Co}^{2+}$ solutions respectively) was checked for the solutions [42,43].

\subsection{Antibacterial Assay for Wastewater Treatment}

The sample pond water was collected from Cooch Behar district, West Bengal, India. Three conical flasks, each containing $10 \mathrm{~mL}$ of sample pond water, were treated separately with $0.05 \mathrm{~g} C \mathrm{CT}-\mathrm{Fe}_{3} \mathrm{O}_{4}$ and $0.05 \mathrm{~g} \mathrm{JC}-\mathrm{Fe}_{3} \mathrm{O}_{4} \mathrm{NPs}$ alongside a blank experiment, and were shaken for $10 \mathrm{~min}$. Then from the stirred solutions, $100 \mu \mathrm{L}$ of the mixture was spread on Luria Broth (LB)-agar plates and were incubated for $24 \mathrm{~h}$ at $37^{\circ} \mathrm{C}$ [44]. For the colony forming units (cfu) calculation, the same process was repeated, using different amounts $(0.04 \mathrm{~g}, 0.02 \mathrm{~g}$ and $0.01 \mathrm{~g})$ for each of CT- $\mathrm{Fe}_{3} \mathrm{O}_{4}$ and $\mathrm{JC}-\mathrm{Fe}_{3} \mathrm{O}_{4} \mathrm{NPs}$.

\subsection{Isolation and Characterization of Bacteria from the Collected Sample}

The collected pond water was serially diluted from $10^{-1}$ to $10^{-15}$ times and each dilution was spread on the LB-agar plate using spread plate technique and incubated for $24 \mathrm{~h}$ at $37^{\circ} \mathrm{C}$. Next, one bacterial single colony was isolated and subcultured to obtain a pure culture. The pure culture was stored in $3 \mathrm{~mL}$ microcentrifuge tube for further assays (Disk Diffusion Test and Minimum inhibitory concentration (MIC) determination). Gram staining was performed on the isolated pure culture. Briefly, loopful of mother culture was taken, and smeared on the glass slide. The smear was air dried and fixed by passing over the flame. A few drops of crystal violet stain were added to the fixed smear and were kept for 1 minute. Then a few drops of iodine solution were added. Next, alcohol washing was done for 25-30 s. Furthermore, a few drops of saffranine were added and kept for $1 \mathrm{~min}$. After every step, excess stain was washed off with water and dried in air, and the slides were observed under a microscope.

\subsubsection{Disk Diffusion Test}

One-hundred microlitres of bacterial suspension ( $0.5 \mathrm{McF}$ arland Standard) was spread over the surface of the LB-Agar plate and allowed to dry for $10 \mathrm{~min}$. Then two sterile paper disk $(5 \mathrm{~mm})$ saturated with $30 \mu \mathrm{L}$ of CT- $-\mathrm{Fe}_{3} \mathrm{O}_{4}$ and another with JC- $\mathrm{Fe}_{3} \mathrm{O}_{4} \mathrm{NPs}(200 \mathrm{ppm})$ were placed in the culture medium. The plates were sealed by parafilm and incubated at $37^{\circ} \mathrm{C}$ for $24 \mathrm{~h}$, and the diameter of the resulting inhibition zone in every plate was measured [45,46]. All the experiments were performed in duplicates, and the results were expressed as mean values.

\subsubsection{Minimum Inhibitory Concentration (MIC) Determination}

MIC of CT- $\mathrm{Fe}_{3} \mathrm{O}_{4}$ and JC- $\mathrm{Fe}_{3} \mathrm{O}_{4}$ NPs were determined by the broth dilution method using microliter-sized wells. The positive control sample contained $100 \mu \mathrm{L}$ of bacteria inoculums with a culture medium in the absence of MNPs. The negative control contained $100 \mu \mathrm{L}$ of culture medium in the absence of MNPs for monitoring sterility. Fifty microlitres of serially diluted CT- $\mathrm{Fe}_{3} \mathrm{O}_{4}$ and JC- $\mathrm{Fe}_{3} \mathrm{O}_{4}$ 
NPs were added to 10 columns containing $50 \mu \mathrm{L}$ of culture medium (LB medium) to maintain the concentration sequence from $4000 \mathrm{ppm}$ to $7.8 \mathrm{ppm}$. The standardized bacterial culture $\left(1 \times 10^{5} \mathrm{cfu} / \mathrm{mL}\right)$ was added in each well from columns 1-10. Further, the microlitre-sized wells were incubated at $37^{\circ} \mathrm{C}$ for $24 \mathrm{~h}$, and the resulting turbidity was observed. The MIC was determined where there was no visible growth of bacteria detected. For further confirmation, the turbidity was measured by optical density readings at $600 \mathrm{~nm}$ with a UV-Vis spectrophotometer $[47,48]$.

\subsubsection{Antibacterial Assay}

\section{Bacteria Culture Preparation}

The commercial bacterial stain of E. coli (ATCC 25922) and S. aureus (ATCC 29213) were grown in $\mathrm{LB}$ medium for $24 \mathrm{~h}$ at $37^{\circ} \mathrm{C}$, and optical density readings were compared to a $0.5 \mathrm{McFarland}$ standard. Both the disk diffusion test and MIC were performed in the same procedure discussed before.

\subsection{2,2-Diphenyl-1-picrylhydrazyl (DPPH) Radical Scavenging Assay}

Free radical scavenging activity was estimated by the DPPH scavenging assay $[49,50] .10 .14 \mu \mathrm{M}$ solution of DPPH in methanol was added to $500 \mu \mathrm{L}$ MNPs solutions in methanol (total volume was $5 \mathrm{~mL}$ ) in different concentrations $(0.06 \mathrm{mg} / \mathrm{mL}, 0.25 \mathrm{mg} / \mathrm{mL}, 0.57 \mathrm{mg} / \mathrm{mL}, 1.00 \mathrm{mg} / \mathrm{mL}, 1.57 \mathrm{mg} / \mathrm{mL})$ and the activity was observed at $517 \mathrm{~nm}$ after keeping the solutions in dark for about $30 \mathrm{~min}$. The control sample was prepared without MNPs. Gallic acid was used as a positive control in all cases. The scavenging activity estimation was performed using the formula.

$$
\text { Scavenging activity }(\%)=\left[\left(A_{o}-A_{s}\right) / A_{o}\right] \times 100
$$

where $A_{o}$ is the absorbance of the control (DPPH + methanol), and $A_{s}$ is the absorbance of the respective sample solutions (sample in methanol + DPPH solution).

\subsection{Measurement of Cytotoxicity Using MTT Assay}

SW480 and HeLa cells $\left(4.5 \times 10^{3}\right.$ cells per well) were seeded into 96-well plates. After $24 \mathrm{~h}$, the media was changed to non-serum RPMI 1640, and after a further $24 \mathrm{~h}$, the cells were treated withJC- $-\mathrm{Fe}_{3} \mathrm{O}_{4}$ and CT- $-\mathrm{Fe}_{3} \mathrm{O}_{4} \mathrm{NPs}$ at different concentrations. The treated cells were incubated for $48 \mathrm{~h}$, washed with cold PBS, and then exposed to MTT with media for $4 \mathrm{~h}$. The media was changed to $\mathrm{DMSO}$, and the dissolved formazan dye was quantified by measuring the absorbance at $540 \mathrm{~nm}$. As a control, untreated cells were examined in the same manner.

\section{Results and Discussion}

\subsection{Synthesis of Nanoparticles}

There are different procedures reported for the synthesis of MNPs by the co-precipitation methods, and most of them require an inert environment and, in some cases, an elevated temperature. Herein our study, we have reported the synthesis of JC- $-\mathrm{Fe}_{3} \mathrm{O}_{4}$ and CT- $-\mathrm{Fe}_{3} \mathrm{O}_{4}$ NPs at room temperature without inert gas environment and elevated temperature. In addition, we have replaced the use of ammonium hydroxide solution with $\mathrm{NaOH}$ solution and this collective approach makes our synthetic procedure much greener than the other reported methods because of environmentally friendly reagents, low toxicity, and biodegradable products [51]. This collective approach makes our synthetic procedure much greener than the methods reported hitherto in the literature.

\subsection{Dynamic Light Scattering Experiment}

Hydrodynamic size measurements are usually greater than the actual size measurements of the MNPs, which is due to the presence of extra hydrated layers attached on the surface. DLS experiment 
showed that hydrated MNPs had average sizes of around $154.2 \mathrm{~nm}$ for JC- $\mathrm{Fe}_{3} \mathrm{O}_{4}$ (Figure 1a) and around $65 \mathrm{~nm}$ for $\mathrm{CT}-\mathrm{Fe}_{3} \mathrm{O}_{4}$ (Figure $1 \mathrm{~b}$ ). Hence, from the DLS graphs, we conclude that the formation of nanoparticles was completed in both the cases since the distributions are more even with a narrow distribution range.

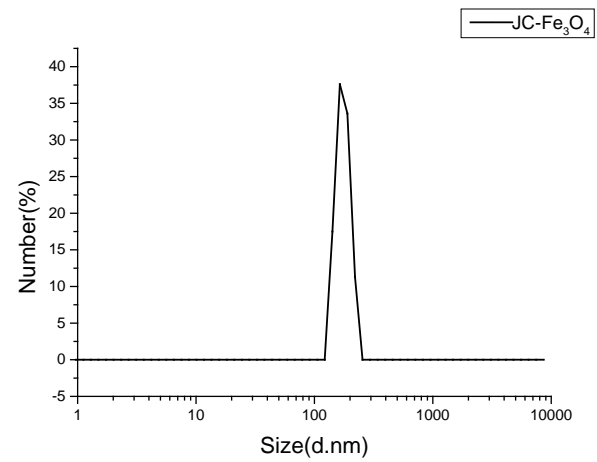

(a)

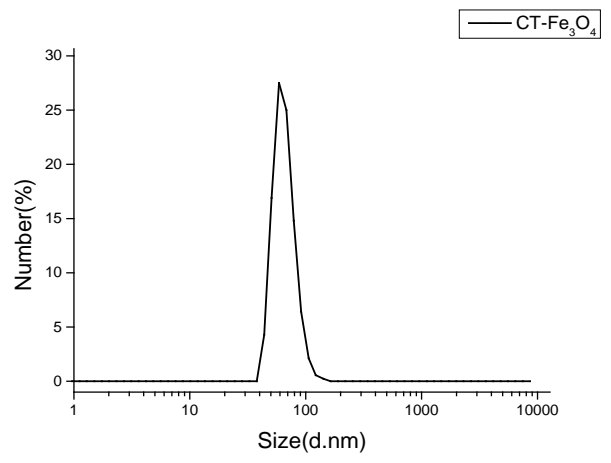

(b)

Figure 1. DLS curve of (a) $\mathrm{JC}-\mathrm{Fe}_{3} \mathrm{O}_{4}$ nanoparticle; (b) $\mathrm{CT}-\mathrm{Fe}_{3} \mathrm{O}_{4}$ nanoparticle.

\subsection{UV-Visible Spectroscopy}

The UV-Vis spectra (Figure 2) exhibited the characteristic continuous peak absorption of both the magnetite nanoparticles in the visible range; the absorption range was between 300-800 $\mathrm{nm}$ [52]. This confirms the formation of iron oxide nanoparticles. From the appearance of a broadband and the absence of any hump spectra, it may be concluded that not much size difference was present in the synthesized nanoparticles.

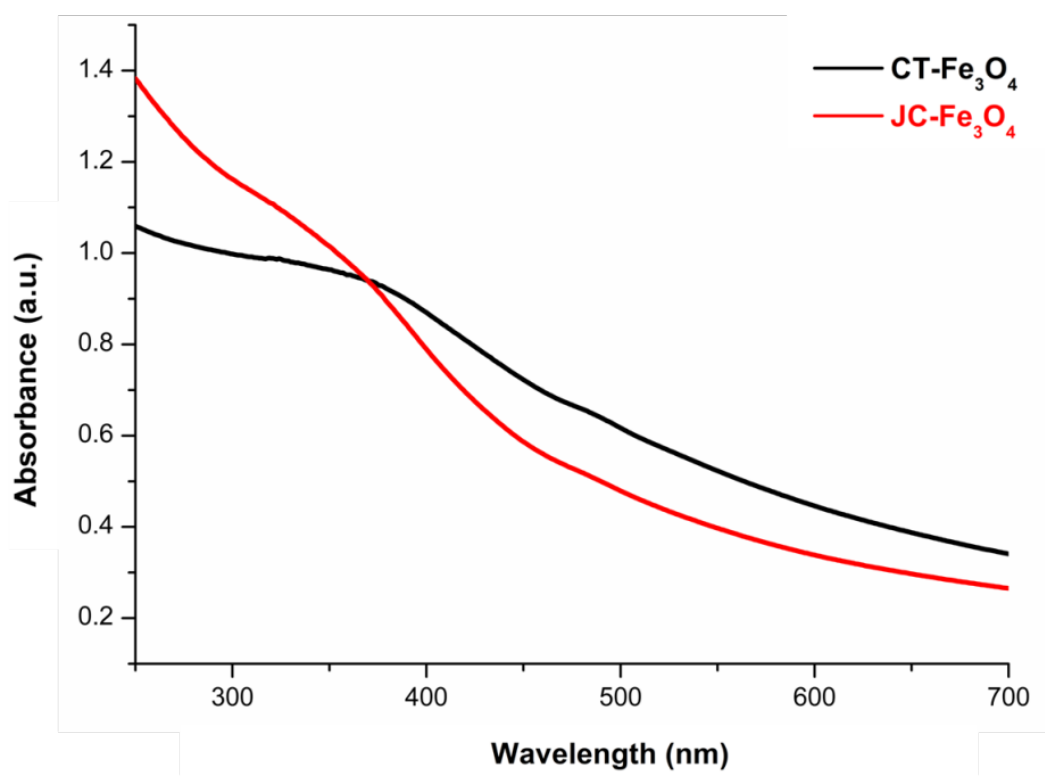

Figure 2. UV-Vis absorption spectra of $\mathrm{CT}-\mathrm{Fe}_{3} \mathrm{O}_{4}$ and $\mathrm{JC}-\mathrm{Fe}_{3} \mathrm{O}_{4} \mathrm{NPs}$.

\subsection{FTIR Spectroscopy}

\subsubsection{FTIR Analysis of JC- $\mathrm{Fe}_{3} \mathrm{O}_{4}$ Nanoparticles}

Next the FTIR analysis was performed to prove the presence of JC latex as the capping material for the synthesized MNPs. Synthesized JC- $\mathrm{Fe}_{3} \mathrm{O}_{4} \mathrm{NPs}$ showed a strong absorption band at $1607 \mathrm{~cm}^{-1}$ (stretching vibration of $\mathrm{C}-\mathrm{N}$ group), which was attributed to the binding of JC latex as the capping 
agent since this peak was also observed to be a significant peak in case of dried JC latex powder at $1618 \mathrm{~cm}^{-1}$ [37]. Other significant FTIR peaks showed the bands at $3248 \mathrm{~cm}^{-1}(\mathrm{~N}-\mathrm{H}$ stretching for amides), $2923 \mathrm{~cm}^{-1}$ (secondary amine), $1373 \mathrm{~cm}^{-1}$ (-CO-stretching), and $1070 \mathrm{~cm}^{-1}$ (O-H stretching), which clearly proved the presence of protein/peptide on the nanoparticle binding surface. This data also fitted well with the previously reported Jatropha curcas extract capped nanoparticles [53] (Figure 3a).

\subsubsection{FTIR Analysis of $\mathrm{CT}-\mathrm{Fe}_{3} \mathrm{O}_{4}$ Nanoparticles}

Similarly, the FTIR peak analysis of CT-Fe $\mathrm{O}_{4}$ NPs revealed that a broadband $3280 \mathrm{~cm}^{-1}$ was due to $\mathrm{O}-\mathrm{H}$ stretching from the eugenol-OH present in the aqueous extract of $\mathrm{CT}$ leaf. The other significant bands at $1620 \mathrm{~cm}^{-1}$ (for carbonyl stretching) match well with the reported CT extract IR at $1638 \mathrm{~cm}^{-1}$ [54]; $2922 \mathrm{~cm}^{-1}$ (for C-H stretching) and $1059 \mathrm{~cm}^{-1}$ (for C-O stretching vibration) confirmed the formation of CT leaves extract-coated MNPs [55] (Figure 3b).
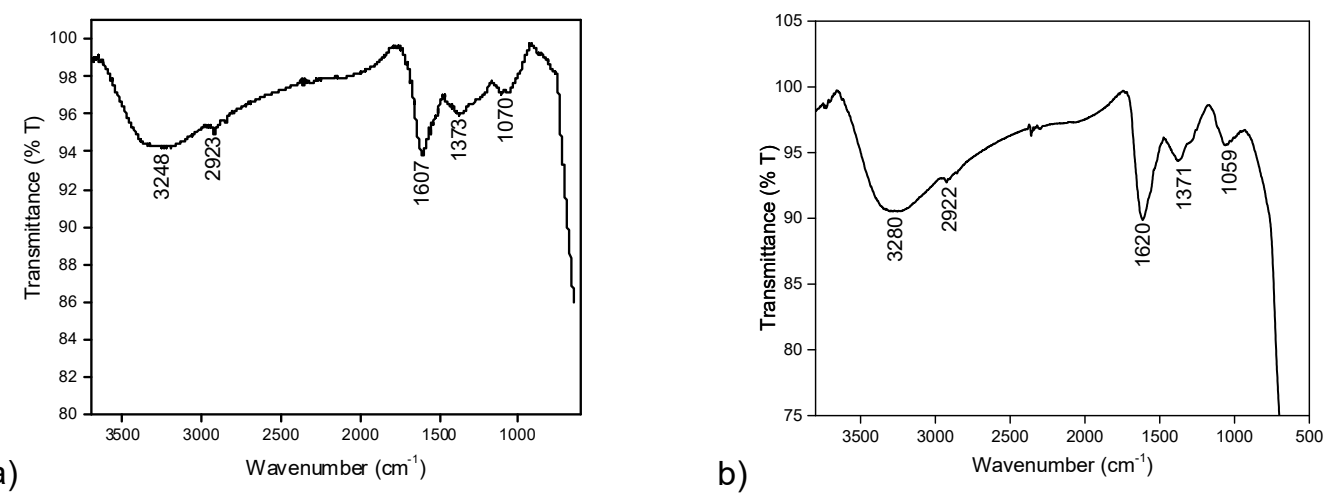

Figure 3. FTIR spectra of (a) $\mathrm{JC}-\mathrm{Fe}_{3} \mathrm{O}_{4}$ and (b) $\mathrm{CT}-\mathrm{Fe}_{3} \mathrm{O}_{4} \mathrm{NPs}$.

\subsection{Powder XRD Analysis of $\mathrm{JC}-\mathrm{Fe}_{3} \mathrm{O}_{4}$ and $\mathrm{CT}-\mathrm{Fe}_{3} \mathrm{O}_{4}$ Nanoparticles}

The X-ray powder diffractograms of the JC- $\mathrm{Fe}_{3} \mathrm{O}_{4}$ (Figure 4a) showed a series of diffraction peaks

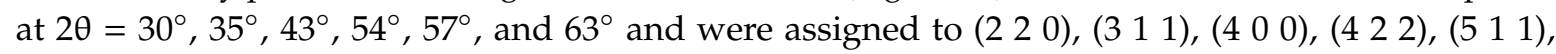
and (4 40 ) planes of cubic structures, which were in good accordance with the inverse cubic spinel phase of $\mathrm{Fe}_{3} \mathrm{O}_{4}$ (magnetite, JCPDS card no. 85-1436). Similarly, for CT-Fe $\mathrm{O}_{4}$ (Figure $4 \mathrm{~b}$ ), the X-ray powder diffractograms showed a series of diffraction peaks at $2 \theta=30^{\circ}, 35^{\circ}, 44^{\circ}, 54^{\circ}, 57^{\circ}$, and $63^{\circ}$

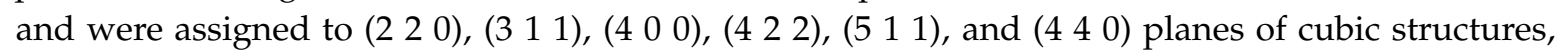
which confirmed the same inverse cubic spinel phase of $\mathrm{Fe}_{3} \mathrm{O}_{4}$ NPs. These results were similar to those reported in the literature [56].

(a)

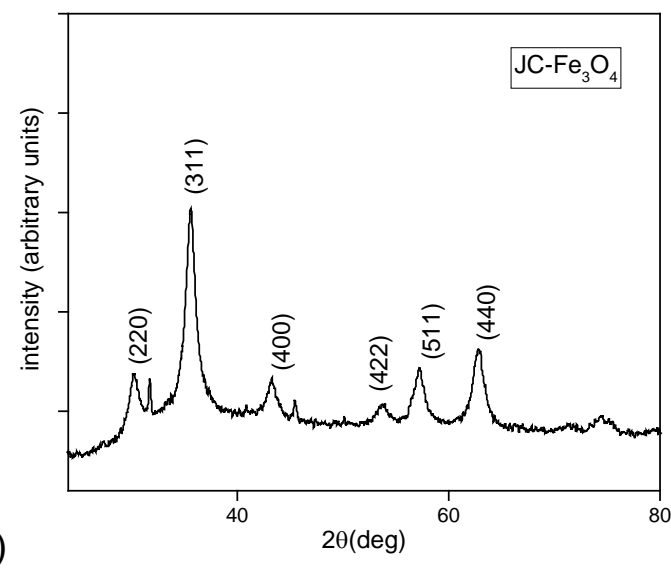

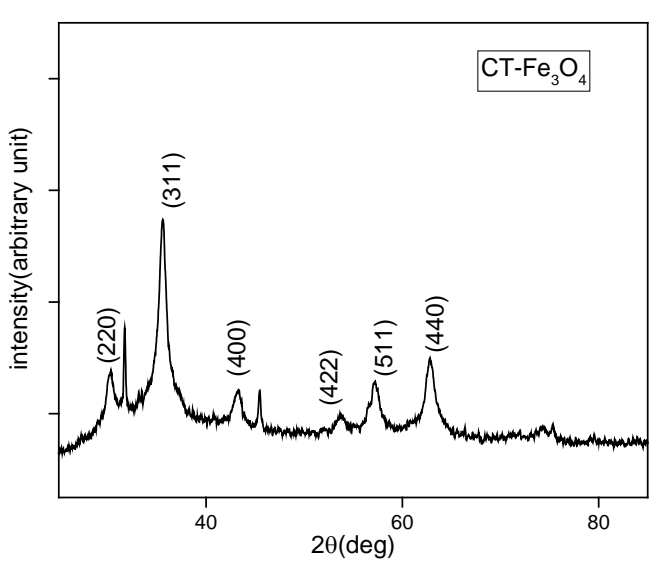

(b)

Figure 4. X-ray diffractometer patterns of MNPs (a) JC-Fe3O4 and (b) CT-Fe3O4. 


\subsection{FE-SEM Analysis}

Analysis of FE-SEM images for JC- $\mathrm{Fe}_{3} \mathrm{O}_{4}$ and CT- $\mathrm{Fe}_{3} \mathrm{O}_{4}$ NPs showed the surface morphology of respective NPs was round-shaped. The size ranges for JC- $\mathrm{Fe}_{3} \mathrm{O}_{4}$ and CT- $-\mathrm{Fe}_{3} \mathrm{O}_{4}$ were $20-42 \mathrm{~nm}$ (Figure 5a) and 26-35 nm (Figure 5b), respectively, and both were well surrounded by the respective green coating. The images confirmed that the formation of natural product-based nanoparticles had a spherical shape.

(a)

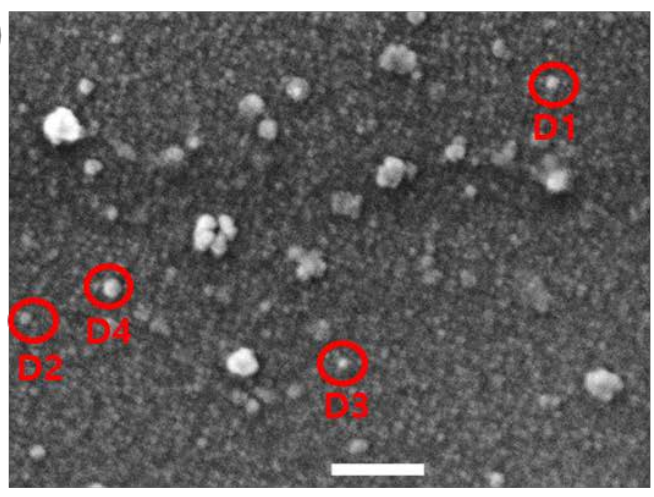

(b)

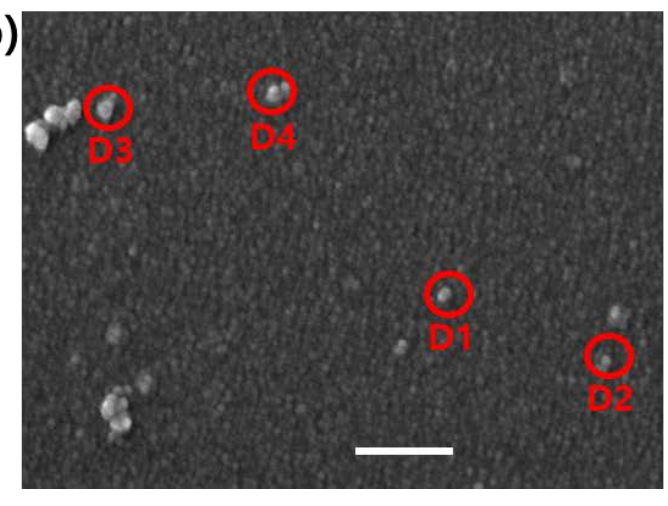

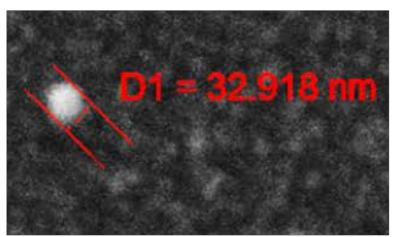
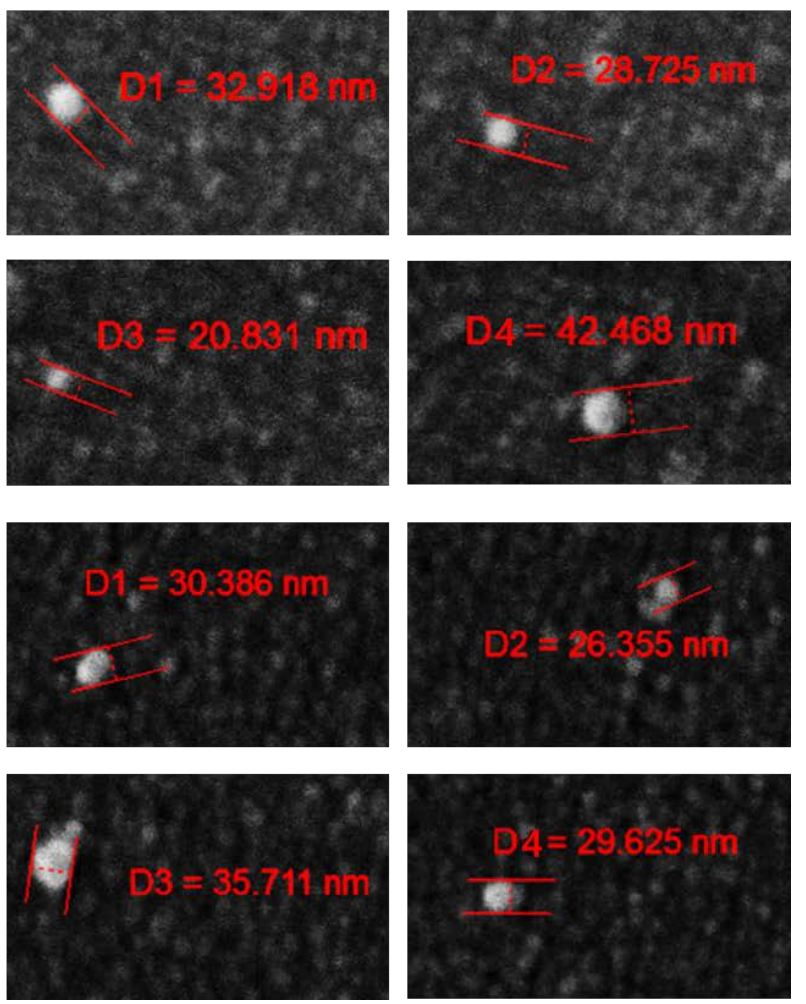

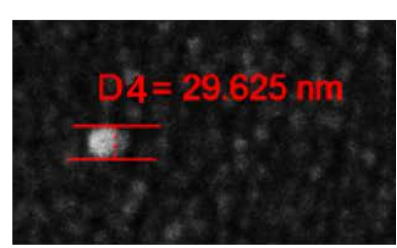

Figure 5. FE-SEM images showing the morphology of (a) $\mathrm{JC}-\mathrm{Fe}_{3} \mathrm{O}_{4}$ and (b) $\mathrm{CT}-\mathrm{Fe}_{3} \mathrm{O}_{4} \mathrm{NPs}$; Left: Single nanoparticles are marked with red circles. Right: Magnification of each single nanoparticle with the measured diameter (scale bar: $200 \mathrm{~nm}$ ).

\subsection{Dye Adsorption Study}

The adsorption of $\mathrm{MB}$ as a model pollutant was performed to evaluate the adsorption ability of synthesized JC- $-\mathrm{Fe}_{3} \mathrm{O}_{4}$ and CT- $\mathrm{Fe}_{3} \mathrm{O}_{4}$ NPs. Two model equilibrium adsorption isotherms, viz., Langmuir adsorption isotherm and Freundlich adsorption isotherm, were applied. For better understanding of the adsorption process, it is important to investigate the relevant kinetics; two different common kinetic models, pseudo-first-order and pseudo-second-order models were studied.

\subsubsection{Dye Adsorption Isotherm of MB Dye}

The Langmuir isotherm accounts for the monolayer surface coverage of the adsorbents while the Freundlich isotherm defines for multilayer adsorption. The linear form of Langmuir and Freundlich isotherm equations are depicted as:

$$
\text { Langmuir model: } C_{e} / Q_{e}=1 /\left(Q_{m} K_{L}\right)+C_{e} / Q_{m}
$$

$$
\text { Freundlich model: } \log Q_{e}=\log K_{F}+(1 / n) \log C_{e}
$$

The adsorption capacity is calculated by the equation: $Q_{e}=\left(C_{o}-C_{e}\right) \times V / m$ 
Another adsorption parameter, $R_{L}$, correlation factor at equilibrium, is also calculated for adsorption of $\mathrm{MB}$ on for Langmuir isotherm using the equation:

$$
R_{L}=1 /\left(1+C_{o} K_{L}\right)
$$

For $0<R_{L}<1$, adsorption process is satisfactory, and for $R_{L} \geq 1$ it is unfavourable.

Where, $C_{o}=$ initial concentration of adsorbate in $\mathrm{mg} / \mathrm{L}, C_{e}=$ equilibrium concentration of (adsorbate + adsorbent), $Q_{e}=$ adsorption capacity in $\mathrm{mg} / \mathrm{g}, K_{L}=$ Langmuir constant, $Q_{m}=$ maximum adsorption capacity, $K_{F}=$ Freundlich constant, $n=$ separation factor, $V=$ total volume of the solution in $\mathrm{L}, m=$ amount of adsorbent in $\mathrm{g}$.

It was observed from Figure 6 a that the removal percentage of MB dye $(200 \mathrm{mg} / \mathrm{L})$ increased with respect to contact time in the presence of JC- $\mathrm{Fe}_{3} \mathrm{O}_{4} \mathrm{NPs}$. The absorption peak of MB dye at $660 \mathrm{~nm}$ gradually decreased with time and after $120 \mathrm{~min}$ the color decreased considerably. Hence, taking $120 \mathrm{~min}$ as the optimum time, we performed further experiments. From Figure 6b, the adsorption capacity of the MNPs increase with increasing concentration of the dye.
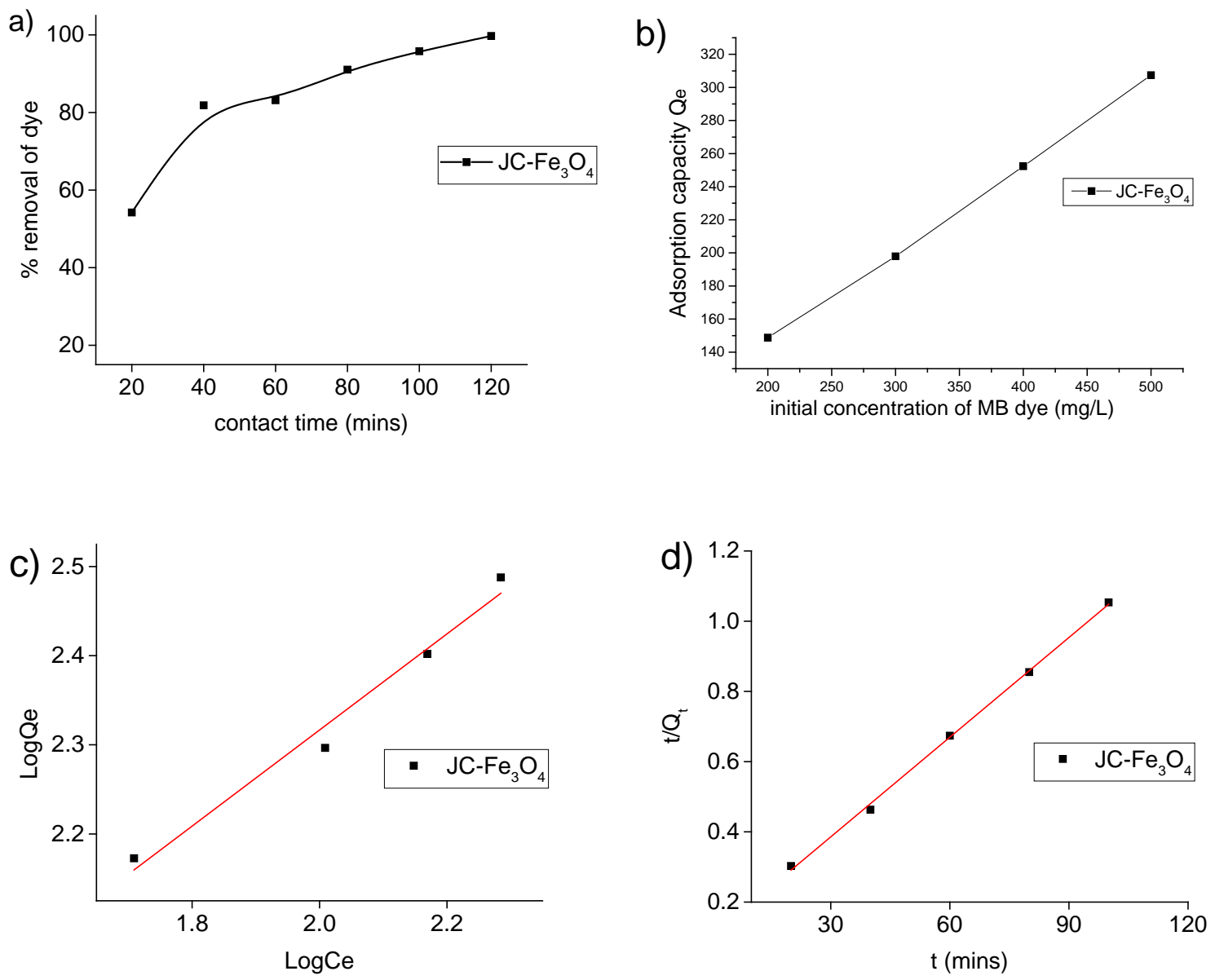

Figure 6. Plot of (a) \% removal of MB dye with contact time; (b) adsorption capacity (Qe) of MB dye with concentration; (c) Freundlich adsorption isotherm model ( $\log Q_{e}$ vs $\log C_{e}$ ); (d) Pseudo-second-order kinetic model for adsorption $t / Q_{t}$ vs. $t$ (mins) of JC-Fe $\mathrm{O}_{4} \mathrm{NPs}$.

From Figure 6b, it is evident that the dye removal capacity of $\mathrm{JC}-\mathrm{Fe}_{3} \mathrm{O}_{4}$ is dependent on the initial concentration of the MB. Thus, the removal capacity is increasing with the increase in the initial concentration of dye. Analysis of data from the plot of [log Qe against $\log \mathrm{Ce}$ ] (Figure 6c) as tabulated in Table 1 supports that for MB dye adsorption, Freundlich model fits better than Langmuir model in case of JC- $-\mathrm{Fe}_{3} \mathrm{O}_{4}$ NPs as the values of $R^{2}$ in the case of Freundlich model are much closer to 1 . 
Table 1. Adsorption isotherm parameters for $\mathrm{MB}$ dye onto $\mathrm{JC}-\mathrm{Fe}_{3} \mathrm{O}_{4}$ adsorbents.

\begin{tabular}{lcccccccc}
\hline \multirow{2}{*}{ Adsorbent } & \multirow{2}{*}{ Adsorbate } & \multicolumn{3}{c}{ Langmuir Isotherm } & \multicolumn{4}{c}{ Freundlich Isotherm } \\
\cline { 3 - 9 } & & $\boldsymbol{Q} \boldsymbol{m}$ & $\boldsymbol{K}_{\boldsymbol{L}}$ & $\boldsymbol{R}_{\boldsymbol{L}}$ & $\boldsymbol{R}^{\mathbf{2}}$ & $\boldsymbol{K}_{\boldsymbol{F}}$ & $\mathbf{1} \boldsymbol{n}$ & $\boldsymbol{R}^{\mathbf{2}}$ \\
\hline $\mathrm{JC}^{-}-\mathrm{Fe}_{3} \mathrm{O}_{4}$ & MB dye & 466.6 & 0.0078 & $0.204-0.340$ & 0.919 & 17.248 & 0.539 & 0.979 \\
\hline
\end{tabular}

\subsubsection{Adsorption Kinetics for MB Dye}

Adsorption kinetics study for $\mathrm{MB}$ dye over synthesized $\mathrm{JC}-\mathrm{Fe}_{3} \mathrm{O}_{4}$ and $\mathrm{CT}-\mathrm{Fe}_{3} \mathrm{O}_{4} \mathrm{NPs}$ wasinvestigated using pseudo-first-order and pseudo-second-order kinetic models. Pseudo-first order and pseudo-second order kinetics were investigated by the following equations [57]:

$$
\begin{gathered}
\text { Pseudo-first-order: } \log \left(Q_{e}-Q_{t}\right)=\log Q_{e}-K_{1} t / 2.303 \\
\text { Pseudo-second-order: } t / Q_{t}=1 / K_{2} Q_{e}{ }^{2}+\mathrm{t} / Q_{e} \\
Q_{t} \text { was calculated by the equation: } Q_{t}=\left(C_{o}-C_{t}\right) V / m
\end{gathered}
$$

where, $K_{1}=$ rate constant of first-order kinetics in $\min ^{-1}, K_{2}=$ rate constant of second order kinetics in $\mathrm{g} / \mathrm{mg} \cdot \mathrm{min}, Q_{e}=$ adsorption capacity at equilibrium in $\mathrm{mg} / \mathrm{g}$, and $Q_{t}=$ adsorption capacity in $\mathrm{mg} / \mathrm{g}$ at time $t$.

All the experimental and calculated data based on the above kinetic models for adsorption of $\mathrm{MB}$ on JC- $\mathrm{Fe}_{3} \mathrm{O}_{4}$ NPs are presented in Table 2. From the results in Table 2 and Figure $6 \mathrm{~d}$, it is seen that although the correlation coefficient $\left(R^{2}\right)$ is almost similar for both the kinetic models, the experimental value of the adsorption capacity $Q_{e}$ (expt) agrees better with the calculated value $Q e$ (cal) based on pseudo-second-order model than with pseudo-first-order model, indicating that our adsorption process follows the former model. No consistent results were observed for the dye adsorption on

\begin{tabular}{|c|c|c|c|c|c|c|c|c|}
\hline \multirow[b]{2}{*}{ Adsorbent } & \multirow[b]{2}{*}{ Adsorbate } & \multirow{2}{*}{$\begin{array}{c}Q_{e}(\operatorname{expt}) \\
(\mathrm{mg} / \mathrm{g})\end{array}$} & \multicolumn{3}{|c|}{ Pseudo-First Order } & \multicolumn{3}{|c|}{ Pseudo-Second Order } \\
\hline & & & $\begin{array}{l}Q_{e}(\mathrm{cal}) \\
(\mathrm{mg} / \mathrm{g})\end{array}$ & $\begin{array}{c}K_{1} \\
\left(\mathrm{~min}^{-1}\right)\end{array}$ & $R^{2}$ & $\begin{array}{l}Q_{e}(\mathrm{cal}) \\
(\mathrm{mg} / \mathrm{g})\end{array}$ & $K_{2}(\mathrm{~g} / \mathrm{mg} \cdot \min )$ & $R^{2}$ \\
\hline $\mathrm{JC}-\mathrm{Fe}_{3} \mathrm{O}_{4}$ & MB dye & 96.25 & 57.67 & 0.0368 & 0.980 & 104.82 & $8.02 \times 10^{-4}$ & 0.998 \\
\hline
\end{tabular}
$\mathrm{CT}-\mathrm{Fe}_{3} \mathrm{O}_{4}$ NPs.

Table 2. Kinetics data with correlation coefficients for $\mathrm{MB}$ dye onto $\mathrm{JC}-\mathrm{Fe}_{3} \mathrm{O}_{4}$.

\subsection{Toxic Metal Adsorption Study (with Concentration)}

There are reports in the existing literature that MNPs have the potential to adsorb heavy as well as toxic metal ions such as $\mathrm{Hg}^{2+}, \mathrm{Cd}^{2+}, \mathrm{Pb}^{2+}, \mathrm{Co}^{2+}, \mathrm{Cu}^{2+}$, etc. [43,58-60]. We have investigated the ability to remove toxic metal ions $\mathrm{Co}^{2+}$ and $\mathrm{Cu}^{2+}$ from aqueous medium via adsorption onto the synthesized JC- $\mathrm{Fe}_{3} \mathrm{O}_{4}$ and CT- $\mathrm{Fe}_{3} \mathrm{O}_{4}$ NPs. To understand the nature of adsorption of the metal ions, we applied our experimental data to the Langmuir and Freundlich adsorption isotherms; the results are presented in Figure $7 \mathrm{a}\left(\right.$ for $\left.\mathrm{Co}^{2+}\right)$, Figure $7 \mathrm{~b}\left(\right.$ for $\left.\mathrm{Cu}^{2+}\right)$, and in Table 3. Table 4 represents a compilation of literature value of adsorption capacity of different adsorbent for $\mathrm{Co}^{2+}$ and $\mathrm{Cu}^{2+}$. From Table 3, it is evident that the values of the correlation coefficient $\left(R^{2}\right)$ for all the ions are greater for Langmuir plot than for Freundlich case, implying that the metal ion adsorption process follows the Langmuir model better than the Freundlich model. The observed maximum adsorption capacity $(Q m)$ of CT- $\mathrm{Fe}_{3} \mathrm{O}_{4} \mathrm{NPs}$ is 513.7 and $463.23 \mathrm{mg} / \mathrm{g}$ for $\mathrm{Co}^{2+}$ and $\mathrm{Cu}^{2+}$ respectively. The corresponding values are 501.3 and $543.3 \mathrm{mg} / \mathrm{g}$ for $\mathrm{JC}-\mathrm{Fe}_{3} \mathrm{O}_{4}$. These values are much better than all other reported values, as seen in Table 4 . 
a)

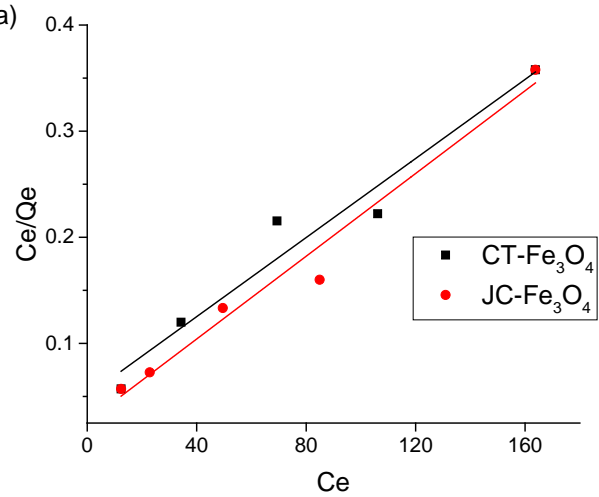

b)

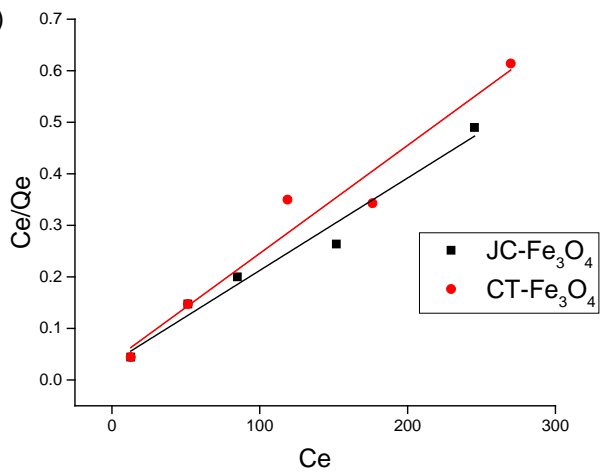

Figure 7. Langmuir isotherm plot for the removal of (a) $\mathrm{Co}^{2+}$ ions and (b) $\mathrm{Cu}^{2+}$ ions by $\mathrm{JC}^{2}-\mathrm{Fe}_{3} \mathrm{O}_{4}$ and $\mathrm{CT}-\mathrm{Fe}_{3} \mathrm{O}_{4}$ NPs.

Table 3. Adsorption isotherm parameters for metal ions onto JC- $\mathrm{Fe}_{3} \mathrm{O}_{4}$ and CT- $-\mathrm{Fe}_{3} \mathrm{O}_{4}$ adsorbents.

\begin{tabular}{ccccccccc}
\hline \multirow{2}{*}{ Adsorbent } & \multirow{2}{*}{ Adsorbate } & \multicolumn{3}{c}{ Langmuir Isotherm } & \multicolumn{4}{c}{ Freundlich Isotherm } \\
\cline { 2 - 9 } & & $Q_{m}$ & $K_{\boldsymbol{L}}$ & $\boldsymbol{R}_{\boldsymbol{L}}$ & $\boldsymbol{R}^{\mathbf{2}}$ & $\boldsymbol{K}_{\boldsymbol{F}}$ & $\mathbf{1} \boldsymbol{n}$ & $\boldsymbol{R}^{\mathbf{2}}$ \\
\hline \multirow{2}{*}{$\mathrm{JC}^{-}-\mathrm{Fe}_{3} \mathrm{O}_{4}$} & $\mathrm{Cu}^{2+}$ & 543.3 & 0.055 & $0.039-0.120$ & 0.974 & 1.079 & 0.226 & 0.861 \\
\cline { 2 - 9 } & $\mathrm{Co}^{2+}$ & 501.3 & 0.076 & $0.036-0.117$ & 0.977 & 1.062 & 0.310 & 0.836 \\
\hline \multirow{2}{*}{$\mathrm{CT}^{2}-\mathrm{Cu}_{3} \mathrm{O}_{4}$} & $\mathrm{Cu}^{2+}$ & 463.24 & 0.059 & $0.030-0.130$ & 0.954 & 1.086 & 0.159 & 0.697 \\
\cline { 2 - 9 } & $\mathrm{Co}^{2+}$ & 513.7 & 0.038 & $0.070-0.209$ & 0.956 & 1.222 & 0.312 & 0.916 \\
\hline
\end{tabular}

Table 4. Comparison of maximum adsorption capacity of CT- $\mathrm{Fe}_{3} \mathrm{O}_{4}$ and $\mathrm{JC}-\mathrm{Fe}_{3} \mathrm{O}_{4}$ with other magnetite nanoparticle adsorbents literature values.

\begin{tabular}{|c|c|c|c|}
\hline Adsorbate & Adsorbent & Adsorption Capacity (mg/g) & Ref. \\
\hline \multirow{6}{*}{$\mathrm{Cu}^{2+}$} & Iron oxide nanoparticles & 17.6 & [61] \\
\hline & GA-MNP & 38.5 & [61] \\
\hline & Amino functionalized magnetic nanosorbent & 12.4 & [62] \\
\hline & $\mathrm{Fe}_{3} \mathrm{O}_{4} / \mathrm{AC}$ & 2.7 & [63] \\
\hline & $\mathrm{CT}-\mathrm{Fe}_{3} \mathrm{O}_{4}$ & 463.2 & Present study \\
\hline & $\mathrm{JC}-\mathrm{Fe}_{3} \mathrm{O}_{4}$ & 543.3 & Present study \\
\hline \multirow{4}{*}{$\mathrm{Co}^{2+}$} & Magnetite-citric acid nanoadsorbent & 43.3 & [64] \\
\hline & $\mathrm{MgFe}_{2} \mathrm{O}_{4}$ & 135.5 & [65] \\
\hline & $\mathrm{CT}-\mathrm{Fe}_{3} \mathrm{O}_{4}$ & 513.7 & Present study \\
\hline & $\mathrm{JC}-\mathrm{Fe}_{3} \mathrm{O}_{4}$ & 501.3 & Present study \\
\hline \multirow{5}{*}{ MB dye } & MNPs-POLP & 128.2 & [66] \\
\hline & Magnetite/pectin NPs & 125 & [67] \\
\hline & Magnetite/silica/pectin NPs & 178.6 & [67] \\
\hline & $\begin{array}{c}\mathrm{Fe}_{3} \mathrm{O}_{4} \text { NPs coated with pectin and } \\
\text { crosslinked with adipic acid (FN-PAA) }\end{array}$ & 221.7 & [68] \\
\hline & $\mathrm{JC}-\mathrm{Fe}_{3} \mathrm{O}_{4}$ & 466.6 & Present study \\
\hline
\end{tabular}

\subsection{Magnetic Properties}

In order to show the magnetic behavior of $\mathrm{JC}-\mathrm{Fe}_{3} \mathrm{O}_{4}$ and $\mathrm{CT}-\mathrm{Fe}_{3} \mathrm{O}_{4} \mathrm{NPs}$, the dispersed solutions (Figure 8a) were treated with magnet externally, and the nanoparticles were found to get deposited 
near the magnet (Figure $8 \mathrm{~b}$ ). This observation also exhibited the possibility of using the powerful magnetic field for the separation of MNPs after wastewater treatment.

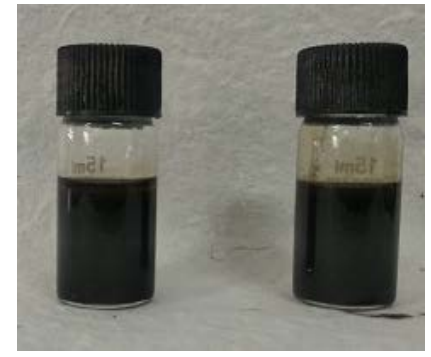

(a)

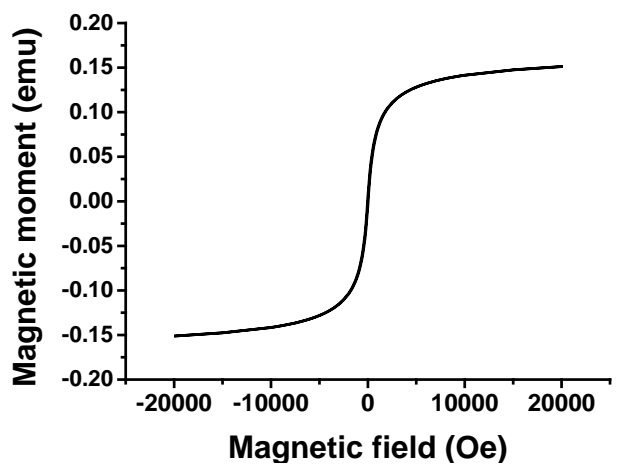

(c)

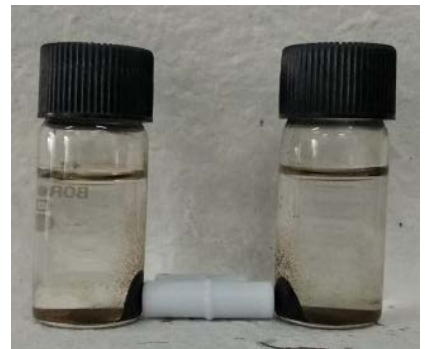

(b)

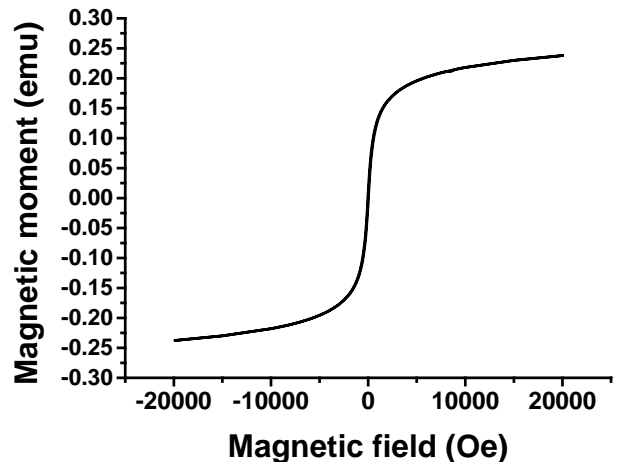

(d)

Figure 8. Respective MNPs solutions; (a) before separation; (b) after using a magnetic bar. VSM analysis of magnetite nanoparticles: (c) $\mathrm{JC}-\mathrm{Fe}_{3} \mathrm{O}_{4}$ and (d) $\mathrm{CT}-\mathrm{Fe}_{3} \mathrm{O}_{4} \mathrm{NPs}$.

Magnetic properties of the synthesized JC- $\mathrm{Fe}_{3} \mathrm{O}_{4}$ and CT- $\mathrm{Fe}_{3} \mathrm{O}_{4}$ NPs were also studied with the help of VSM (Vibrating sample magnetometer). Figure $8 \mathrm{c}, \mathrm{d}$ gives the changes in the magnetization with the applied magnetic field. The superparamagnetic natures of the nanoparticles were confirmed by the absence of the hysteresis loop. The saturation magnetization for JC- $-\mathrm{Fe}_{3} \mathrm{O}_{4}$ and CT- $-\mathrm{Fe}_{3} \mathrm{O}_{4} \mathrm{NPs}$ was found to be 38.46 and $34.35 \mathrm{emu} / \mathrm{g}$, respectively.

\subsection{Antibacterial Assay}

\subsubsection{Characterization of Bacteria Isolated from Pond Water}

The collected pond water (without nanoparticles) was serially diluted, a single colony was isolated, and pure culture was generated. Gram staining was performed on the isolated bacterial culture and was found to be Gram-positive bacteria.

\subsubsection{Wastewater Treatment}

$\mathrm{Fe}_{3} \mathrm{O}_{4} \mathrm{NPs}$ had been previously reported in the literature to exhibit antibacterial activity [69-71]. Similarly, CT leaves were also reported to show antibacterial efficacy [35] as well as JC latex [53,72]. Hence, the antibacterial activity of CT- $-\mathrm{Fe}_{3} \mathrm{O}_{4}$ and JC- $-\mathrm{Fe}_{3} \mathrm{O}_{4} \mathrm{NPs}$ were examined. The amount of bacteria colony was observed to be reduced by more than $50 \%$ in the case of the pond water treated with CT- $-\mathrm{Fe}_{3} \mathrm{O}_{4}$ (Figure $9 \mathrm{~b}$ ) and JC- $\mathrm{Fe}_{3} \mathrm{O}_{4} \mathrm{NPs}$ (Figure 9c) compared to the pond water that was not treated (Figure 9a) with any of the antibacterial agents. The CFU value also showed that the amount of bacteria colony of water treated with nanoparticles was being reduced with increasing the amount of nanoparticles. These observations confirmed the antibacterial activity of CT- $\mathrm{Fe}_{3} \mathrm{O}_{4}$ and JC- $\mathrm{Fe}_{3} \mathrm{O}_{4}$ against various types of water-borne bacteria (Figure 9d). 

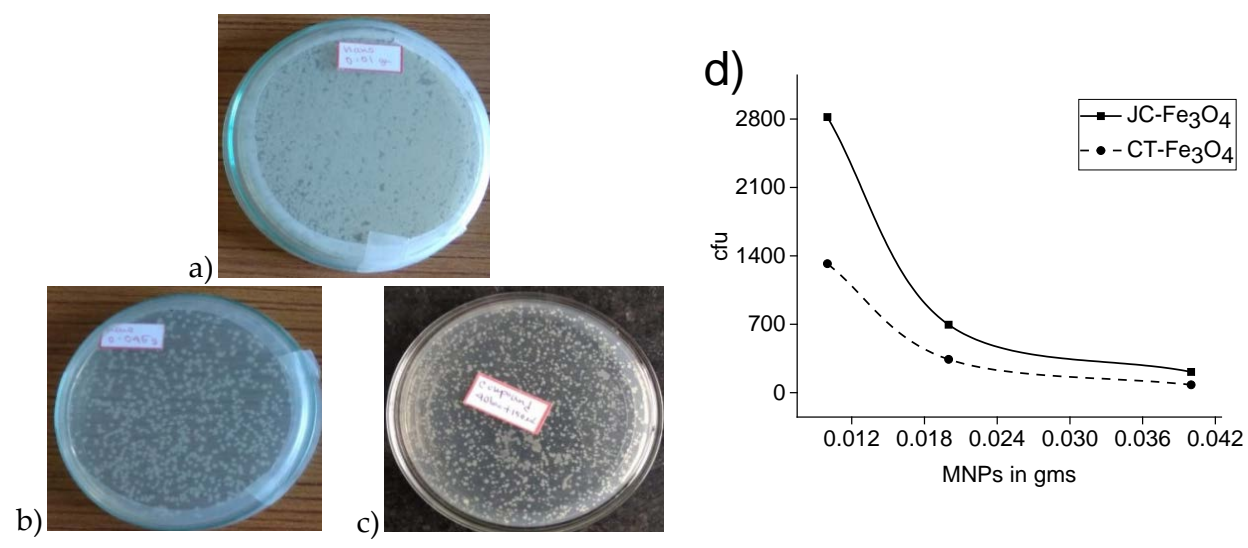

Figure 9. Images of bacterial culture: (a) untreated pond water; (b) with CT- $\mathrm{Fe}_{3} \mathrm{O}_{4}$; (c) with $\mathrm{JC}-\mathrm{Fe}_{3} \mathrm{O}_{4}$; (d) bacterial concentration with respect to amount of MNPs.

\subsubsection{Disk Diffusion}

The antibacterial activities of $\mathrm{CT}-\mathrm{Fe}_{3} \mathrm{O}_{4}$ and $\mathrm{JC}-\mathrm{Fe}_{3} \mathrm{O}_{4}$ NPs measured in terms of zone of inhibition (ZOI) are shown in Figure 10. It was observed that ZOI against water-born Gram-positive bacteria for $\mathrm{CT}-\mathrm{Fe}_{3} \mathrm{O}_{4}$ and $\mathrm{JC}-\mathrm{Fe}_{3} \mathrm{O}_{4}$ NPs showed a diameter of $10 \mathrm{~mm}$ and $7 \mathrm{~mm}$ respectively (Figure 10a,b). In the case of E. coli, ZOI was found to be the same (i.e., $7 \mathrm{~mm}$ ) for both MNPs (Figure 10c,d). However, against $S$. aureus for CT-Fe $\mathrm{O}_{4}$ the $\mathrm{ZOI}$ was $8 \mathrm{~mm}$, whereas for $\mathrm{CT}-\mathrm{Fe}_{3} \mathrm{O}_{4}$ it was $6.5 \mathrm{~mm}$ (Figure 10e,f). Based on the above result, it was observed that both $\mathrm{CT}-\mathrm{Fe}_{3} \mathrm{O}_{4}$ and $\mathrm{JC}-\mathrm{Fe}_{3} \mathrm{O}_{4} \mathrm{NPs}$ exhibited quite effective antibacterial property against both Gram-positive and Gram-negative bacteria. The relative antibacterial activity of the two synthesized nanoparticles has been summarized in Figure $10 \mathrm{~g}$.

(a)

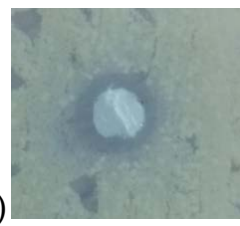

(b)

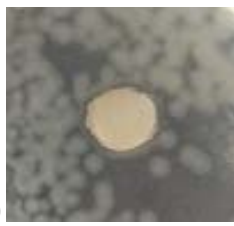

(c)

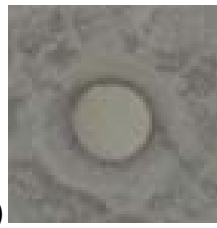

(d)

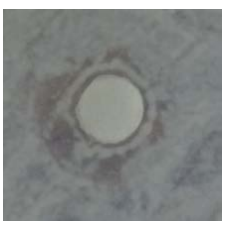

(e)

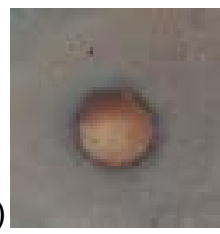

(f)

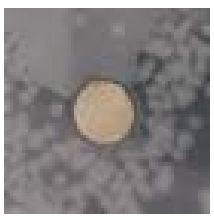

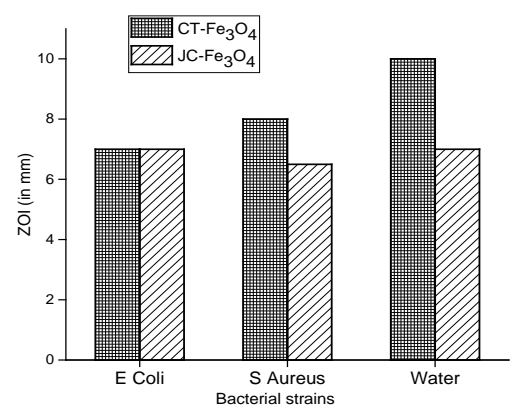

(g)

Figure 10. ZOI against water-born Gram-positive bacteria using (a) CT- $\mathrm{Fe}_{3} \mathrm{O}_{4} \mathrm{NPs}$ (10 mm diameter) and (b) $\mathrm{JC}-\mathrm{Fe}_{3} \mathrm{O}_{4} \mathrm{NPs}$ (7 mm diameter); ZOI against E. coli (Gram-negative bacteria) (c) $\mathrm{CT}-\mathrm{Fe}_{3} \mathrm{O}_{4}$ NPs (7 mm diameter)and (d) $\mathrm{JC}_{-} \mathrm{Fe}_{3} \mathrm{O}_{4} \mathrm{NPs}$ (7 mm diameter); ZOI against $S$. aureus (Gram-positive bacteria) (e) $\mathrm{CT}-\mathrm{Fe}_{3} \mathrm{O}_{4} \mathrm{NPs}\left(8 \mathrm{~mm}\right.$ diameter) and (f) $\mathrm{JC}-\mathrm{Fe}_{3} \mathrm{O}_{4} \mathrm{NPs}$ (6.5 mm diameter). (g) Relative zone of inhibition of CT- $\mathrm{Fe}_{3} \mathrm{O}_{4}$ and $\mathrm{JC}-\mathrm{Fe}_{3} \mathrm{O}_{4}$ NPs against different bacteria. 
The result of the disk diffusion test showed that CT- $-\mathrm{Fe}_{3} \mathrm{O}_{4}$ NPs exhibited better antibacterial activity than that of JC- $\mathrm{Fe}_{3} \mathrm{O}_{4}$ NPs. JC- $\mathrm{Fe}_{3} \mathrm{O}_{4}$ showed similar results for Gram-positive and Gram-negative bacteria, but CT- $\mathrm{Fe}_{3} \mathrm{O}_{4}$ was shown to be more effective against Gram-positive bacteria.

\subsection{4. $\mathrm{MIC}$ of CT-Fe $\mathrm{O}_{4}$ and $\mathrm{JC}-\mathrm{Fe}_{3} \mathrm{O}_{4} \mathrm{NPs}$}

MIC values of CT- $-\mathrm{Fe}_{3} \mathrm{O}_{4}$ and $\mathrm{JC}-\mathrm{Fe}_{3} \mathrm{O}_{4}$ against gram-positive and gram-negative bacteria are shown in Figure 11. For E. coli (gram-negative bacteria), the MIC value for both CT- $-\mathrm{Fe}_{3} \mathrm{O}_{4}$ and JC- $\mathrm{Fe}_{3} \mathrm{O}_{4}$ was observed to be $500 \mathrm{ppm}$. Against $\mathrm{S}$. aureus (gram-positive bacteria), the MIC value for $\mathrm{CT}-\mathrm{Fe}_{3} \mathrm{O}_{4}$ and $\mathrm{JC}-\mathrm{Fe}_{3} \mathrm{O}_{4}$ was $500 \mathrm{ppm}$ and $1000 \mathrm{ppm}$ respectively. In this regard, against the water-borne isolated Gram-positive bacteria, for CT- $\mathrm{Fe}_{3} \mathrm{O}_{4}$, the MIC was $250 \mathrm{ppm}$ and for JC- $\mathrm{Fe}_{3} \mathrm{O}_{4}$ it was $500 \mathrm{ppm}$ (Figure 11).

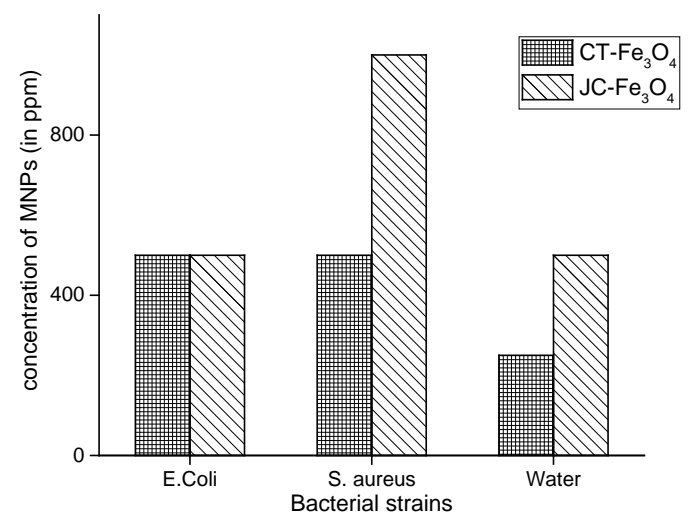

Figure 11. Minimum Inhibitory Concentration (MIC) for different bacteria.

From the MIC, we got the expected results similar to disk diffusion test i.e., both $\mathrm{CT}-\mathrm{Fe}_{3} \mathrm{O}_{4}$ and JC- $\mathrm{Fe}_{3} \mathrm{O}_{4} \mathrm{NPs}$, which showed decent antibacterial property. CT- $-\mathrm{Fe}_{3} \mathrm{O}_{4} \mathrm{NPs}$ were found to be more effective than JC- $\mathrm{Fe}_{3} \mathrm{O}_{4}$ NPs against both the Gram-positive and Gram-negative bacteria.

\subsection{DPPH Scavenging Assay}

The antioxidant properties of both the nanoparticles (JC- $\mathrm{Fe}_{3} \mathrm{O}_{4}$ and CT- $\mathrm{Fe}_{3} \mathrm{O}_{4} \mathrm{NPs}$ ) are shown in Figure 12. The DPPH scavenging assay of the respective MNPs resulted in $\mathrm{IC}_{50}$ values of $0.30 \mathrm{mg} / \mathrm{mL}$ for JC- $\mathrm{Fe}_{3} \mathrm{O}_{4}$, and for CT- $\mathrm{Fe}_{3} \mathrm{O}_{4}$ it was $0.67 \mathrm{mg} / \mathrm{mL}$; and the $\mathrm{IC}_{50}$ value for the uncoated $\mathrm{Fe}_{3} \mathrm{O}_{4}$ nanoparticle was estimated to be $1.40 \mathrm{mg} / \mathrm{mL}$. The chosen standard (positive control) was the gallic acid solution in methanol. All the concentrations were taken as $0.06 \mathrm{mg} / \mathrm{mL}, 0.25 \mathrm{mg} / \mathrm{mL}, 0.57 \mathrm{mg} / \mathrm{mL}, 1.00 \mathrm{mg} / \mathrm{mL}$, and $1.57 \mathrm{mg} / \mathrm{mL}$ in methanol.

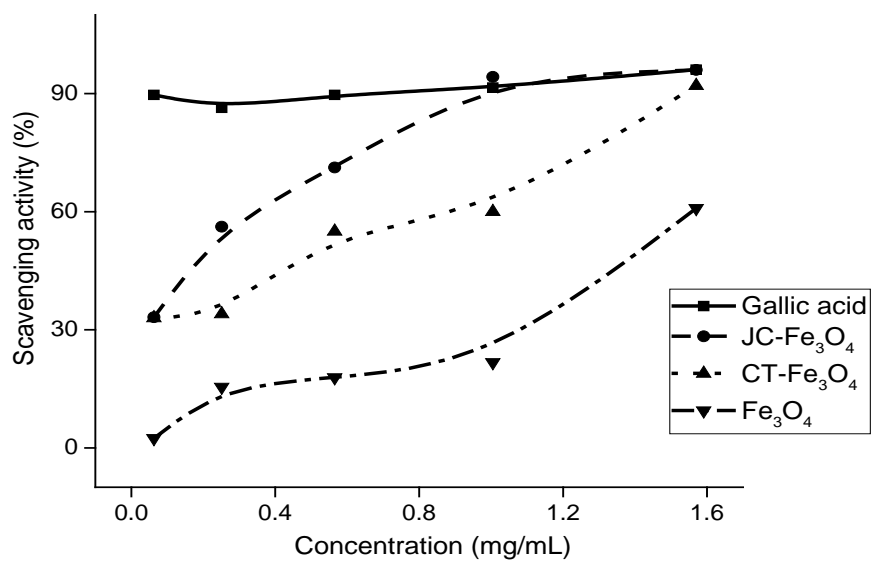

Figure 12. DPPH scavenging activity (\%) of MNPs and standard gallic acid solution. 


\subsection{Measurement of Cytotoxicity Using MTT Assay}

In addition to more efficient water purifying capabilities of the natural product-coated MNPs, it is important to study the overall toxicity associated with them. Since treated water, may consist of residual MNPs in ppm level due to inefficient removal process. It is reported that coated MNPs also showed lower cytotoxicity towards cancerous cells than the uncoated one [73]. Hence, to investigate whether the synthesized coated MNPs are toxic to human cells, cytotoxicity was investigated against human cancer cell lines (SW480 and HeLa) by MTT assay. Each cell line was incubated with both the MNPs for $48 \mathrm{~h}$ in different concentrations (Figure 13), and then the percentage viability of the cells was estimated. The percentage viability of the cells was found to be little enhanced in $\mathrm{CT}-\mathrm{Fe}_{3} \mathrm{O}_{4}$ and almost remained the same in $\mathrm{JC}_{-} \mathrm{Fe}_{3} \mathrm{O}_{4}$. Based on the in vitro cytotoxicity results, it can be concluded that the MNPs did not exhibit cytotoxicity towards both cell lines, indicating these MNPs are not harmful to human cells. These results were well corroborated with the previous literature with natural product-coated MNPs [74].
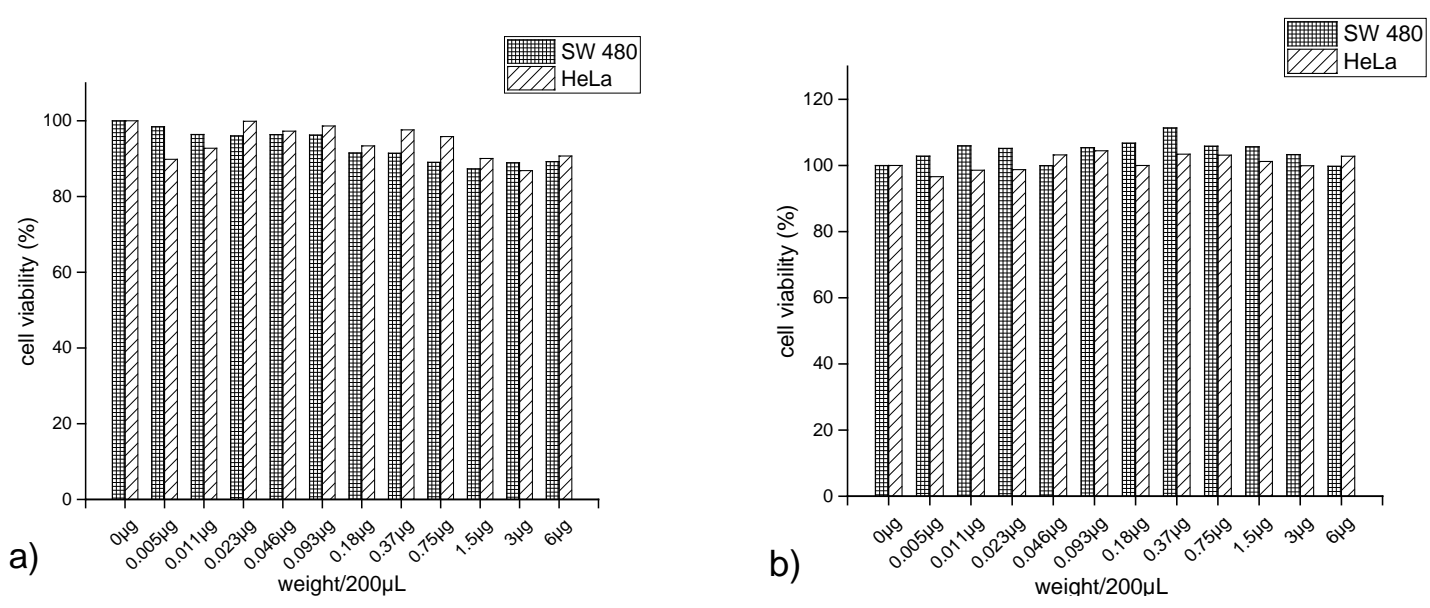

Figure 13. In vitro cytotoxicity of (a) $\mathrm{JC}-\mathrm{Fe}_{3} \mathrm{O}_{4} \mathrm{NPs}$ and (b) $\mathrm{CT}-\mathrm{Fe}_{3} \mathrm{O}_{4} \mathrm{NPs}$ against $\mathrm{SW} 480$ and HeLa cells assessed by MTT assays. Cytotoxicity is given as the percentage of viable cells remaining after treatment.

\section{Conclusions}

The present study reports the green syntheses of two natural products, coated $\mathrm{JC}-\mathrm{Fe}_{3} \mathrm{O}_{4}$ and $\mathrm{CT}-\mathrm{Fe}_{3} \mathrm{O}_{4}$ NPs. Both the synthesized MNPs are effective in removing the content of wastewater like organic dyes and toxic metal ions. The study also shows that the nanoparticles are effective as antibacterial agents (both Gram-positive and Gram-negative bacteria) as well as antioxidant agents. Both the coated MNPs also do not exhibit any cytotoxic effect, as shown by the MTT assay. Therefore, JC- $\mathrm{Fe}_{3} \mathrm{O}_{4}$ and $\mathrm{CT}-\mathrm{Fe}_{3} \mathrm{O}_{4}$ NPs both show promise for environment-friendly composites for effective water treatment.

Author Contributions: Conceptualization, C.D., S.S., S.S.P. and G.B.; Data curation, C.D., S.S., T.S. and T.G. Formal analysis, C.D., S.S., T.S., T.G. and T.W.K.; Funding acquisition, J.I.; Investigation, C.D., S.S. and T.W.K. Project administration, S.J., D.K.M., J.I. and G.B.; Supervision, S.S.P., S.J., D.K.M., J.I. and G.B.; Writing-original draft, C.D., S.S., T.G., T.W.K. and S.J.; Writing-review \& editing, T.S., S.S.P., D.K.M., J.I. and G.B. All authors have read and agreed to the published version of the manuscript.

Funding: This work was supported by the National Research Foundation of Korea (NRF) grant funded by the Korea government (MSIT). (No. NRF-2019R1H1A2039759) and also supported by the Korea Institute of Energy Technology Evaluation and Planning (KETEP) and the Ministry of Trade, Industry \& Energy (MOTIE) of the Republic of Korea (No. 20184030202130).

Acknowledgments: G.B. also expresses gratitude to Dilip Debnath, CBPBU and Gobinda Ch De, CBPBU for their guidance.

Conflicts of Interest: The authors declare no conflict of interest. 


\section{References}

1. Boretti, A.; Rosa, L. Reassessing the projections of the World Water Development Report. Npj Clean Water 2019, 2, 15. [CrossRef]

2. Gutierrez, A.M.; Dziubla, T.D.; Hilt, J.Z. Recent advances on iron oxide magnetic nanoparticles as sorbents of organic pollutants in water and wastewater treatment. Rev. Environ. Health 2017, 32, 111-117. [CrossRef] [PubMed]

3. Agarwal, M.; Singh, K. Heavy metal removal from wastewater using various adsorbents: A review. J. Water Reuse Desalin. 2017, 7, 387-419. [CrossRef]

4. Mehdipour, S.; Vatanpour, V.; Kariminia, H.-R. Influence of ion interaction on lead removal by a polyamide nanofiltration membrane. Desalination 2015, 362, 84-92. [CrossRef]

5. Ivanets, A.I.; Srivastava, V.; Kitikova, N.V.; Shashkova, I.L.; Sillanpää, M. Kinetic and thermodynamic studies of the $\mathrm{Co}(\mathrm{II})$ and $\mathrm{Ni}$ (II) ions removal from aqueous solutions by Ca-Mg phosphates. Chemosphere 2017, 171, 348-354. [CrossRef]

6. Tran, H.N.; Nguyen, H.C.; Woo, S.H.; Nguyen, T.V.; Vigneswaran, S.; Hosseini-Bandegharaei, A.; Rinklebe, J.; Kumar Sarmah, A.; Ivanets, A.; Dotto, G.L.; et al. Removal of various contaminants from water by renewable lignocellulose-derived biosorbents: A comprehensive and critical review. Crit. Rev. Environ. Sci. Technol. 2019, 49, 2155-2219. [CrossRef]

7. Ivanets, A.I.; Srivastava, V.; Kitikova, N.V.; Shashkova, I.L.; Sillanpää, M. Non-apatite Ca-Mg phosphate sorbent for removal of toxic metal ions from aqueous solutions. J. Environ. Chem. Eng. 2017, 5, 2010-2017. [CrossRef]

8. Singh, N.B.; Nagpal, G.; Agrawal, S. Rachna Water purification by using Adsorbents: A Review. Environ. Technol. Innov. 2018, 11, 187-240. [CrossRef]

9. Crini, G.; Lichtfouse, E.; Wilson, L.D.; Morin-Crini, N. Conventional and non-conventional adsorbents for wastewater treatment. Environ. Chem. Lett. 2019, 17, 195-213. [CrossRef]

10. Ivanets, A.I.; Shashkova, I.L.; Kitikova, N.V.; Drozdova, N.V. Extraction of Co(II) ions from aqueous solutions with thermally activated dolomite. Russ. J. Appl. Chem. 2014, 87, 270-275. [CrossRef]

11. Rodrigues, T.S.; da Silva, A.G.M.; Camargo, P.H.C. Nanocatalysis by noble metal nanoparticles: Controlled synthesis for the optimization and understanding of activities. J. Mater. Chem. A 2019, 7, 5857-5874. [CrossRef]

12. Malekzad, H.; SahandiZangabad, P.; Mirshekari, H.; Karimi, M.; Hamblin, M.R. Noble metal nanoparticles in biosensors: Recent studies and applications. Nanotechnol. Rev. 2017, 6. [CrossRef] [PubMed]

13. Bhirde, A.; Xie, J.; Swierczewska, M.; Chen, X. Nanoparticles for cell labeling. Nanoscale 2011, 3, $142-153$. [CrossRef] [PubMed]

14. Patra, J.K.; Das, G.; Fraceto, L.F.; Campos, E.V.R.; del Pilar Rodriguez-Torres, M.; Acosta-Torres, L.S.; Diaz-Torres, L.A.; Grillo, R.; Swamy, M.K.; Sharma, S.; et al. Nano based drug delivery systems: Recent developments and future prospects. J. Nanobiotechnol. 2018, 16, 71. [CrossRef] [PubMed]

15. Kannan, U.M.; Giribabu, L.; Jammalamadaka, S.N. Demagnetization field driven charge transport in a TiO2 based dye sensitized solar cell. Sol. Energy 2019, 187, 281-289. [CrossRef]

16. Dhathathreyan, K.S.; Rajalakshmi, N.; Balaji, R. Nanomaterials for Fuel Cell Technology. In Nanotechnology for Energy Sustainability; Raj, B., Van de Voorde, M., Mahajan, Y., Eds.; Wiley-VCH Verlag GmbH \& Co. KGaA: Weinheim, Germany, 2017; pp. 569-596. ISBN 978-3-527-69610-9.

17. Venditti, I. Gold Nanoparticles in Photonic Crystals Applications: A Review. Materials 2017, 10, 97. [CrossRef] [PubMed]

18. Rizvi, S.A.A.; Saleh, A.M. Applications of nanoparticle systems in drug delivery technology. Saudi Pharm. J. 2018, 26, 64-70. [CrossRef] [PubMed]

19. Martinez-Boubeta, C.; Simeonidis, K. Magnetic Nanoparticles for Water Purification. In Nanoscale Materials in Water Purification; Elsevier: Amsterdam, The Netherlands, 2019; pp. 521-552. ISBN 978-0-12-813926-4.

20. Najafpoor, A.; Norouzian-Ostad, R.; Alidadi, H.; Rohani-Bastami, T.; Davoudi, M.; Barjasteh-Askari, F.; Zanganeh, J. Effect of magnetic nanoparticles and silver-loaded magnetic nanoparticles on advanced wastewater treatment and disinfection. J. Mol. Liq. 2020, 303, 112640. [CrossRef]

21. Hou, S.; Jia, S.; Jia, J.; He, Z.; Li, G.; Zuo, Q.; Zhuang, H. $\mathrm{Fe}_{3} \mathrm{O}_{4}$ nanoparticles loading on cow dung based activated carbon as an efficient catalyst for catalytic microbubble ozonation of biologically pretreated coal gasification wastewater. J. Environ. Manag. 2020, 267, 110615. [CrossRef] 
22. Ansari, S.; Ficiarà, E.; Ruffinatti, F.; Stura, I.; Argenziano, M.; Abollino, O.; Cavalli, R.; Guiot, C.; D'Agata, F. Magnetic Iron Oxide Nanoparticles: Synthesis, Characterization and Functionalization for Biomedical Applications in the Central Nervous System. Materials 2019, 12, 465. [CrossRef]

23. Gul, S.; Khan, S.B.; Rehman, I.U.; Khan, M.A.; Khan, M.I. A Comprehensive Review of Magnetic Nanomaterials Modern Day Theranostics. Front. Mater. 2019, 6, 179. [CrossRef]

24. Mohammed, L.; Gomaa, H.G.; Ragab, D.; Zhu, J. Magnetic nanoparticles for environmental and biomedical applications: A review. Particuology 2017, 30,1-14. [CrossRef]

25. Tai, M.F.; Lai, C.W.; Abdul Hamid, S.B. Facile Synthesis Polyethylene Glycol Coated Magnetite Nanoparticles for High Colloidal Stability. J. Nanomater. 2016, 2016, 1-7. [CrossRef]

26. Fathy, M.M.; Fahmy, H.M.; Saad, O.A.; Elshemey, W.M. Silica-coated iron oxide nanoparticles as a novel nano-radiosensitizer for electron therapy. Life Sci. 2019, 234, 116756. [CrossRef] [PubMed]

27. Yang, H.; Zhang, J.; Liu, Y.; Wang, L.; Bai, L.; Yang, L.; Wei, D.; Wang, W.; Niu, Y.; Chen, H. Rapid removal of anionic dye from water by poly(ionic liquid)-modified magnetic nanoparticles. J. Mol. Liq. 2019, 284, 383-392. [CrossRef]

28. Griffin, S.; Masood, M.; Nasim, M.; Sarfraz, M.; Ebokaiwe, A.; Schäfer, K.-H.; Keck, C.; Jacob, C. Natural Nanoparticles: A Particular Matter Inspired by Nature. Antioxidants 2017, 7, 3. [CrossRef]

29. Kudr, J.; Haddad, Y.; Richtera, L.; Heger, Z.; Cernak, M.; Adam, V.; Zitka, O. Magnetic Nanoparticles: From Design and Synthesis to Real World Applications. Nanomaterials 2017, 7, 243. [CrossRef]

30. Arias, L.; Pessan, J.; Vieira, A.; Lima, T.; Delbem, A.; Monteiro, D. Iron Oxide Nanoparticles for Biomedical Applications: A Perspective on Synthesis, Drugs, Antimicrobial Activity, and Toxicity. Antibiotics 2018, 7, 46. [CrossRef]

31. Nagajyothi, P.C.; Pandurangan, M.; Kim, D.H.; Sreekanth, T.V.M.; Shim, J. Green Synthesis of Iron Oxide Nanoparticles and Their Catalytic and In Vitro Anticancer Activities. J. Clust. Sci. 2017, 28, 245-257. [CrossRef]

32. Fahmy, H.M.; Mohamed, F.M.; Marzouq, M.H.; Mustafa, A.B.E.-D.; Alsoudi, A.M.; Ali, O.A.; Mohamed, M.A.; Mahmoud, F.A. Review of Green Methods of Iron Nanoparticles Synthesis and Applications. BioNanoScience 2018, 8, 491-503. [CrossRef]

33. Nam, N.H.; Luong, N.H. Nanoparticles: Synthesis and applications. In Materials for Biomedical Engineering; Elsevier: Amsterdam, The Netherlands, 2019; pp. 211-240. ISBN 978-0-08-102814-8.

34. Pochhi, M.L. An antioxidant activity of Cinnamonumtamala improves histopathological alterations and biochemical parameters in alloxan induced diabetic rats. Asian J. Med. Sci. 2019, 10, 50-56. [CrossRef]

35. Hassan, W.; Zainab Kazmi, S.N. Antimicrobial Activity of Cinnamomumtamala Leaves. J. Nutr. Disord. Ther. 2015, 6. [CrossRef]

36. Huang, Q.; Guo, Y.; Fu, R.; Peng, T.; Zhang, Y.; Chen, F. Antioxidant activity of flavonoids from leaves of Jatropha curcas. ScienceAsia 2014, 40, 193. [CrossRef]

37. Bar, H.; Bhui, D.K.; Sahoo, G.P.; Sarkar, P.; De, S.P.; Misra, A. Green synthesis of silver nanoparticles using latex of Jatropha curcas. Colloids Surf. Physicochem. Eng. Asp. 2009, 339, 134-139. [CrossRef]

38. Zambri, N.D.S.; Taib, N.I.; Abdul Latif, F.; Mohamed, Z. Utilization of Neem Leaf Extract on Biosynthesis of Iron Oxide Nanoparticles. Molecules 2019, 24, 3803. [CrossRef]

39. Meenachi, S.; Kandasamy, S. Investigation of tannery liming waste water using green synthesised iron oxide nano particles. Int. J. Environ. Anal. Chem. 2019, 99, 1286-1297. [CrossRef]

40. Khan, S.; Setua, S.; Kumari, S.; Dan, N.; Massey, A.; Hafeez, B.B.; Yallapu, M.M.; Stiles, Z.E.; Alabkaa, A.; Yue, J.; et al. Superparamagnetic iron oxide nanoparticles of curcumin enhance gemcitabine therapeutic response in pancreatic cancer. Biomaterials 2019, 208, 83-97. [CrossRef]

41. Sawafta, R.; Shahwan, T. A comparative study of the removal of methylene blue by iron nanoparticles from water and water-ethanol solutions. J. Mol. Liq. 2019, 273, 274-281. [CrossRef]

42. NorouzianBaghani, A.; Mahvi, A.H.; Gholami, M.; Rastkari, N.; Delikhoon, M. One-Pot synthesis, characterization and adsorption studies of amine-functionalized magnetite nanoparticles for removal of $\mathrm{Cr}$ (VI) and $\mathrm{Ni}$ (II) ions from aqueous solution: Kinetic, isotherm and thermodynamic studies. J. Environ. Health Sci. Eng. 2016, 14, 11. [CrossRef] [PubMed]

43. Almomani, F.; Bhosale, R.; Khraisheh, M.; Kumar, A.; Almomani, T. Heavy metal ions removal from industrial wastewater using magnetic nanoparticles (MNP). Appl. Surf. Sci. 2020, 506, 144924. [CrossRef] 
44. Subha, V.; Divya, K.; Gayathri, S.; Jagan Mohan, E.; Keerthanaa, N.; Vinitha, M.; Kirubanandan, S.; Renganathan, S. Applications of iron oxide nano composite in waste water treatment-dye decolourisation and anti-microbial activity. MOJ Drug Des. Dev. Ther. 2018, 2. [CrossRef]

45. Cunha, F.A.; Maia, K.R.; Mallman, E.J.; Cunha, M.D.; Maciel, A.A.; Souza, I.P.; Menezes, E.A.; Fechine, P.B. Silver Nanoparticles-disk diffusion test against Escherichia coli isolates. Rev. Inst. Med. Trop. S. Paulo 2016, 58. [CrossRef] [PubMed]

46. Azam, A.; Ahmed, A.S.; Oves, M.; Khan, M.S.; Habib, S.S.; Memic, A. Antimicrobial activity of metal oxide nanoparticles against Gram-positive and Gram-negative bacteria: A comparative study. Int. J. Nanomedicine 2012, 6003. [CrossRef] [PubMed]

47. Balouiri, M.; Sadiki, M.; Ibnsouda, S.K. Methods for in vitro evaluating antimicrobial activity: A review. J. Pharm. Anal. 2016, 6, 71-79. [CrossRef]

48. Bussmann, R.W.; Malca-García, G.; Glenn, A.; Sharon, D.; Chait, G.; Díaz, D.; Pourmand, K.; Jonat, B.; Somogy, S.; Guardado, G.; et al. Minimum inhibitory concentrations of medicinal plants used in Northern Peru as antibacterial remedies. J. Ethnopharmacol. 2010, 132, 101-108. [CrossRef]

49. Neupane, B.P.; Chaudhary, D.; Paudel, S.; Timsina, S.; Chapagain, B.; Jamarkattel, N.; Tiwari, B.R. Himalayan honey loaded iron oxide nanoparticles: Synthesis, characterization and study of antioxidant and antimicrobial activities. Int. J. Nanomedicine 2019, 14, 3533-3541. [CrossRef]

50. Vashisht, S.; Singh, M.P.; Chawla, V. In-vitro Antioxidant and Antibacterial Activity of Methanolic Extract of ShorearobustaGaertn. F. Resin. Int. J. Pharm. Phytopharm. Res. 2016, 6, 68. [CrossRef]

51. Schwaminger, S.P.; Syhr, C.; Berensmeier, S. Controlled Synthesis of Magnetic Iron Oxide Nanoparticles: Magnetite or Maghemite? Crystals 2020, 10, 214. [CrossRef]

52. Yew, Y.P.; Shameli, K.; Miyake, M.; Kuwano, N.; Bt Ahmad Khairudin, N.B.; Bt Mohamad, S.E.; Lee, K.X. Green Synthesis of Magnetite $\left(\mathrm{Fe}_{3} \mathrm{O}_{4}\right)$ Nanoparticles Using Seaweed (Kappaphycusalvarezii) Extract. Nanoscale Res. Lett. 2016, 11, 276. [CrossRef]

53. Chauhan, N.; Tyagi, A.K.; Kumar, P.; Malik, A. Antibacterial Potential of Jatropha curcas Synthesized Silver Nanoparticles against Food Borne Pathogens. Front. Microbiol. 2016, 7. [CrossRef]

54. Nahar, K.; Aziz, S.; Bashar, M.; Haque, M.A.; Al-Reza, S.M. Synthesis and characterization of Silver nanoparticles from Cinnamomumtamala leaf extract and its antibacterial potential. Int. J. Nano Dimens. 2020, 11, 88-98.

55. Agarwal, H.; Nakara, A.; Menon, S.; Shanmugam, V. Eco-friendly synthesis of zinc oxide nanoparticles using Cinnamomum Tamala leaf extract and its promising effect towards the antibacterial activity. J. Drug Deliv. Sci. Technol. 2019, 53, 101212. [CrossRef]

56. Silva, V.A.; Andrade, P.L.; Silva, M.P.; Valladares, L.D.; Aguiar, J.A. Synthesis and characterization of $\mathrm{Fe}_{3} \mathrm{O}_{4}$ nanoparticles coated with fucan polysaccharides. J. Magn. Magn. Mater. 2013, 343, 138-143. [CrossRef]

57. Yakar, A.; Ünlü, A.; Yeşilçayır, T.; Bıyık, İ. Kinetics and thermodynamics of textile dye removal by adsorption onto iron oxide nanoparticles. Nanotechnol. Environ. Eng. 2020, 5, 6. [CrossRef]

58. El-Dib, F.I.; Mohamed, D.E.; El-Shamy, O.A.A.; Mishrif, M.R. Study the adsorption properties of magnetite nanoparticles in the presence of different synthesized surfactants for heavy metal ions removal. Egypt. J. Pet. 2020, 29, 1-7. [CrossRef]

59. Yang, J.; Hou, B.; Wang, J.; Tian, B.; Bi, J.; Wang, N.; Li, X.; Huang, X. Nanomaterials for the Removal of Heavy Metals from Wastewater. Nanomaterials 2019, 9, 424. [CrossRef]

60. Chowdhury, S.R.; Yanful, E.K. Arsenic and chromium removal by mixed magnetite-maghemite nanoparticles and the effect of phosphate on removal. J. Environ. Manag. 2010, 91, 2238-2247. [CrossRef]

61. Banerjee, S.S.; Chen, D.-H. Fast removal of copper ions by gum arabic modified magnetic nano-adsorbent. J. Hazard. Mater. 2007, 147, 792-799. [CrossRef]

62. Huang, S.-H.; Chen, D.-H. Rapid removal of heavy metal cations and anions from aqueous solutions by an amino-functionalized magnetic nano-adsorbent. J. Hazard. Mater. 2009, 163, 174-179. [CrossRef]

63. Jain, M.; Yadav, M.; Kohout, T.; Lahtinen, M.; Garg, V.K.; Sillanpää, M. Development of iron oxide/activated carbon nanoparticle composite for the removal of $\mathrm{Cr}(\mathrm{VI}), \mathrm{Cu}(\mathrm{II})$ and $\mathrm{Cd}(\mathrm{II})$ ions from aqueous solution. Water Resour. Ind. 2018, 20, 54-74. [CrossRef]

64. Tizro, S.; Baseri, H. Removal of Cobalt Ions from Contaminated Water Using Magnetite Based Nanocomposites: Effects of Various Parameters on the Removal Efficiency. J. Water Environ. Nanotechnol. 2017, 2. [CrossRef] 
65. Ivanets, A.I.; Srivastava, V.; Roshchina, M.Y.; Sillanpää, M.; Prozorovich, V.G.; Pankov, V.V. Magnesium ferrite nanoparticles as a magnetic sorbent for the removal of $\mathrm{Mn} 2+, \mathrm{Co} 2+, \mathrm{Ni} 2+$ and $\mathrm{Cu} 2+$ from aqueous solution. Ceram. Int. 2018, 44, 9097-9104. [CrossRef]

66. Madrakian, E.; Ghaemi, E.; Ahmadi, M. Magnetic Solid Phase Extraction and Removal of Five Cationic Dyes from Aqueous Solution Using Magnetite Nanoparticle Loaded Platanusorientalis Waste Leaves. Anal. Bioanal. Chem. Res. 2016, 3. [CrossRef]

67. Attallah, O.A.; Al-Ghobashy, M.A.; Nebsen, M.; Salem, M.Y. Removal of cationic and anionic dyes from aqueous solution with magnetite/pectin and magnetite/silica/pectin hybrid nanocomposites: Kinetic, isotherm and mechanism analysis. RSC Adv. 2016, 6, 11461-11480. [CrossRef]

68. Rakhshaee, R.; Panahandeh, M. Stabilization of a magnetic nano-adsorbent by extracted pectin to remove methylene blue from aqueous solution: A comparative studying between two kinds of cross-likened pectin. J. Hazard. Mater. 2011, 189, 158-166. [CrossRef]

69. Gabrielyan, L.; Hovhannisyan, A.; Gevorgyan, V.; Ananyan, M.; Trchounian, A. Antibacterial effects of iron oxide $\left(\mathrm{Fe}_{3} \mathrm{O}_{4}\right)$ nanoparticles: Distinguishing concentration-dependent effects with different bacterial cells growth and membrane-associated mechanisms. Appl. Microbiol. Biotechnol. 2019, 103, 2773-2782. [CrossRef]

70. Prabhu, Y.T.; Rao, K.V.; Kumari, B.S.; Kumar, V.S.S.; Pavani, T. Synthesis of Fe3O4 nanoparticles and its antibacterial application. Int. Nano Lett. 2015, 5, 85-92. [CrossRef]

71. Salem, D.M.S.A.; Ismail, M.M.; Aly-Eldeen, M.A. Biogenic synthesis and antimicrobial potency of iron oxide (Fe3O4) nanoparticles using algae harvested from the Mediterranean Sea, Egypt. Egypt. J. Aquat. Res. 2019, 45, 197-204. [CrossRef]

72. Suhaili, Z.; Yeo, C.C.; Yasin, H.N.; Badaludin, N.A.; Zakaria, Z.A. Antibacterial profile of Jatropha curcas latex extracts against selected human pathogenic bacteria. Afr. J. Microbiol. Res. 2011, 5. [CrossRef]

73. Patil, R.M.; Thorat, N.D.; Shete, P.B.; Bedge, P.A.; Gavde, S.; Joshi, M.G.; Tofail, S.A.M.; Bohara, R.A. Comprehensive cytotoxicity studies of superparamagnetic iron oxide nanoparticles. Biochem. Biophys. Rep. 2018, 13, 63-72. [CrossRef]

74. Patil, U.; Adireddy, S.; Jaiswal, A.; Mandava, S.; Lee, B.; Chrisey, D. In Vitro/In Vivo Toxicity Evaluation and Quantification of Iron Oxide Nanoparticles. Int. J. Mol. Sci. 2015, 16, 24417-24450. [CrossRef] [PubMed]

(C) 2020 by the authors. Licensee MDPI, Basel, Switzerland. This article is an open access article distributed under the terms and conditions of the Creative Commons Attribution (CC BY) license (http://creativecommons.org/licenses/by/4.0/). 